\title{
Review \\ Noninvasive Urine-Based Tests to Diagnose or Detect Recurrence of Bladder Cancer
}

\author{
Marine Charpentier ${ }^{1,+}$, Charly Gutierrez ${ }^{1,+}$, Thierry Guillaudeux ${ }^{1}$, Grégory Verhoest ${ }^{2}$ and Rémy Pedeux ${ }^{1, * \mathbb{D}}$ \\ 1 COSS (Chemistry Oncogenesis Stress Signaling)—UMR_S 1242, University of Rennes, INSERM, \\ CLCC Eugène Marquis, F-35000 Rennes, France; marine.charpentier@univ-rennes1.fr (M.C.); \\ charly.gutierrez@univ-rennes1.fr (C.G.); thierry.guillaudeux@univ-rennes1.fr (T.G.) \\ 2 Department of Urology, CHU RENNES, Rue Henri le Guilloux, 35033 Rennes, France; \\ Gregory.Verhoest@chu-rennes.fr \\ * Correspondence: remy.pedeux@univ-rennes1.fr; Tel.: +33-223-234-702 \\ + These authors contributed equally to this paper as first authors.
}

Citation: Charpentier, M.; Gutierrez, C.; Guillaudeux, T.; Verhoest, G.; Pedeux, R. Noninvasive Urine-Based Tests to Diagnose or Detect Recurrence of Bladder Cancer. Cancers 2021, 13, 1650. https:// doi.org/10.3390/cancers13071650

Academic Editor: Roman Blaheta

Received: 5 February 2021

Accepted: 25 March 2021

Published: 1 April 2021

Publisher's Note: MDPI stays neutral with regard to jurisdictional claims in published maps and institutional affiliations.

Copyright: () 2021 by the authors. Licensee MDPI, Basel, Switzerland. This article is an open access article distributed under the terms and conditions of the Creative Commons Attribution (CC BY) license (https:// creativecommons.org/licenses/by/ $4.0 /)$.
Simple Summary: Bladder cancer (BC) is the tenth most common cancer worldwide, with approximatively 550,000 new cases and 200,000 deaths in 2018. BC is divided into two subgroups: non-muscle invasive bladder cancer, an early stage of the cancer, and muscle invasive bladder cancer, which is more aggressive. The crucial issue today is to be able to detect $\mathrm{BC}$ easily and early, with high sensitivity and specificity, in order to treat it sooner, using less invasive methods. Over the past decade, progress has been made to improve detection methods using novel urinary biomarkers. In this review, we discuss the present and future of noninvasive urine tests to diagnose or detect the recurrence of bladder cancer.

Abstract: Liquid biopsies are increasingly used for the diagnosis and follow-up of cancer patients. Urine is a body fluid that can be used to detect cancers and others diseases. It is noninvasive and easy to collect. To detect Bladder Cancer (BC), cytology is the first assay used. It is an effective way to detect high grade $B C$ but has a high rate of equivocal results, especially for low grade BC. Furthermore, cystoscopy is used to confirm cytology results and to determine cancer status. Cystoscopy is also effective but highly invasive, and not well accepted by patients, especially for BC follow-up. In this review we survey the numerous assays recently developed in order to diagnose $\mathrm{BC}$ at an early stage, and to facilitate the follow-up of patients. We discuss their effectiveness, ease of use, and applications. Finally, we discuss assays that, in the future, could improve the diagnosis and management of BC patients.

Keywords: bladder cancer; diagnostic; non-invasive; liquid biopsy; cytology; urine

\section{Introduction}

Bladder cancer (BC) is the tenth most common cancer worldwide, with approximatively 550,000 new cases and 200,000 deaths in 2018. The incidence is 9.6 and 2.4 per 100,000 in males and females, respectively. In France, 12,000 new cases were diagnosed in 2012, and it is the seventh most common cancer [1]. It is the most expensive cancer to treat in Europe [2]. Seventy to eighty five percent of BCs are urothelial carcinoma (UC), commonly termed non-muscle invasive bladder cancer (NMIBC) [3]. Squamous, adenocarcinoma, and small cell carcinoma are less common, and are associated with an advanced stage and higher mortality than NMIBC. NMIBC is an early stage of cancer and is classified as stage Ta to T1; it is only found in the first layer (urothelium) and the second layer (lamina propria) of the bladder (Figure 1). Muscle Invasive Bladder Cancers (MIBC) are classified as T2 to $\mathrm{T} 4$, and are only found in the third layer of the bladder (muscularis propria) (Figure 1). The staging of BC is determined by the TNM system [4]. 


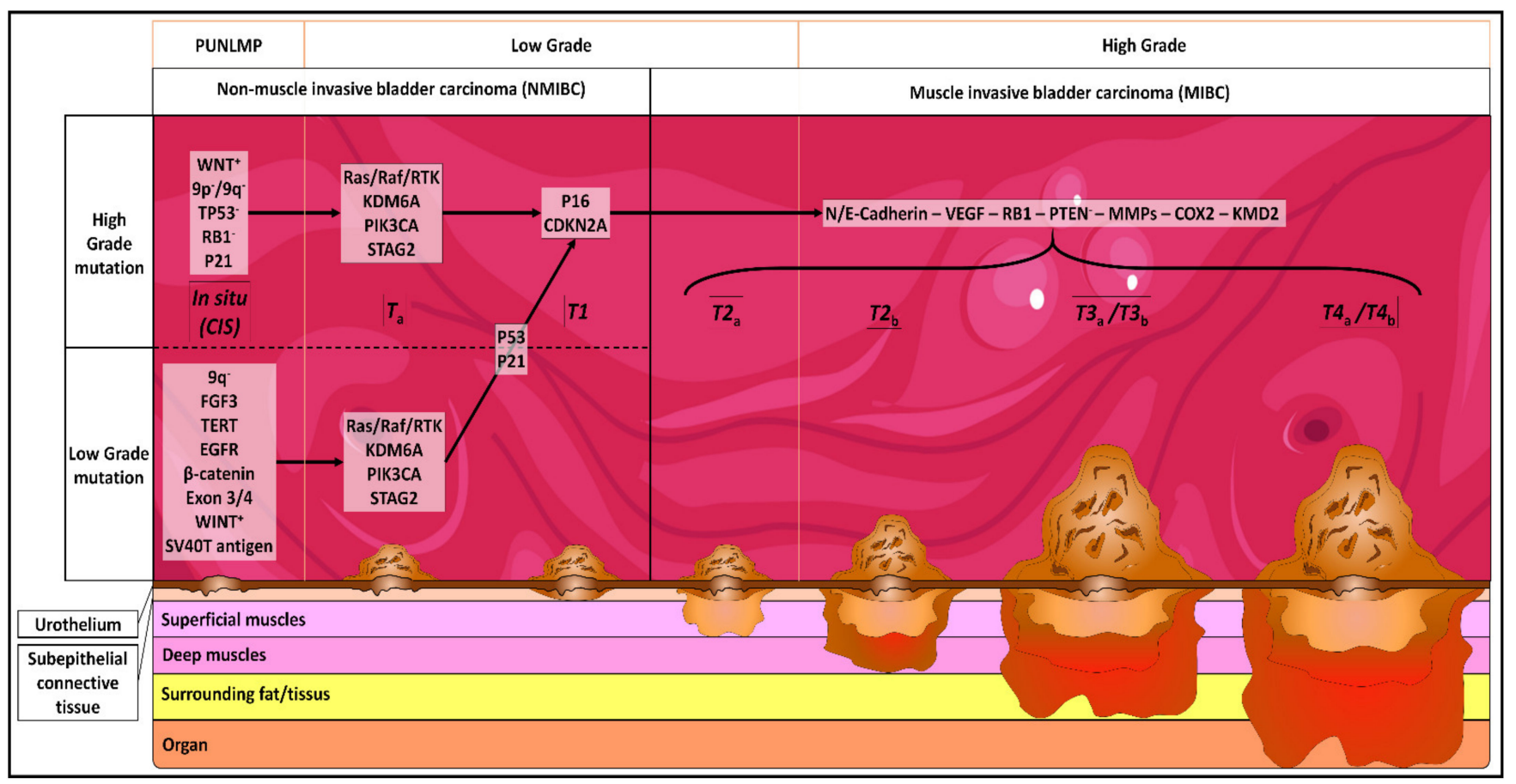

Figure 1. Genetical and physiological evolution of bladder cancer (BC). CIS: carcinoma in situ: "flat tumor"; $\mathrm{T}_{a}$ : noninvasive papillary carcinoma; $\mathrm{T} 1$ : tumor invades subepithelial connective tissue; $\mathrm{T} 2_{a}$ : tumor invades superficial muscularis propria (inner half); $\mathrm{T} 2_{b}$ : tumor invades deep muscularis propria (outer half); $\mathrm{T} 3_{a}$ : tumor invades surrounding fat/tissues microscopically; $\mathrm{T}_{b}$ : tumor invades surrounding fat/tissues macroscopically; $\mathrm{T}_{a}$ : tumor invades prostatic stroma, uterus, vagina; $\mathrm{T}_{b}$ : tumor invades pelvic wall, abdominal wall. PUNLMP = papillary urothelial neoplasm of low malignant potential.

The best-known risk factor for BC development is tobacco smoking. Smoking is responsible for approximately two-thirds of BCs in men and one-third in women [5]. The second most common risk is exposure to specific chemical products. These products are especially present in paint, plastic, printing, textile, or rubber industries (e.g., aromatic amines, polycyclic aromatic hydrocarbons). The five-year survival rate for low grade NMIBC is $96 \%$, dropping to $35 \%$ for MBIC and $5 \%$ for metastatic MBIC. With current diagnostic techniques, only $10 \%$ of low grade NMIBC are detected, due to the difficulty of differentiating low grade cancerous cells from healthy cells. In recent years, many biomarkers for detecting, in particular, low-grade $\mathrm{BC}$ have been described and used to develop new diagnostic tests (Table 1 ).

The first step to detect $B C$ is the presence of a painless visible hematuria [5], the most common symptom in BC, followed by irritative urinary symptoms. These symptoms could also be due to other diseases, such as renal cancer, prostate cancer, interstitial cystitis, renal calculi, benign prostatic hyperplasia, and trauma [6]. Different tests can be used at this point in order to find out the cause of these symptoms. In the case of BC suspicion, several tests exist (Figure 2). One of them is urine cytology. It consists of a microscopic observation of the cells present in the urine of the patient after Papanicolaou staining. The samples are analyzed by the pathologist according to the Paris System guidelines [7]. Urine cytology is an easy assay to perform, and it has a sensitivity of 37\% (95\% CI 35-39\%) and a specificity of $95 \%$ (95\% CI $94-95 \%$ ). It has good results for the detection of high-grade tumors. Moreover, it is a low-cost method. However, the real issue with this test is its low sensitivity for low-grade lesions and its high rate of equivocal results [8]. Therefore, it is always used in combination with cystoscopy to confirm the diagnostic. 
Table 1. Genes altered in $\mathrm{BC}$ and used to develop urine-based diagnostic tests.

\begin{tabular}{|c|c|c|c|c|c|c|c|}
\hline Pathway & Altered Genes & Denomination & Activity & Fonction & $\begin{array}{l}\text { Status in Bladder } \\
\text { Cancer }\end{array}$ & $\begin{array}{l}\text { Alterations Consequences } \\
\text { in BC/Remarks }\end{array}$ & Publications \\
\hline \multirow{4}{*}{$\begin{array}{l}\text { DNA damage } \\
\text { signaling and } \\
\text { repair }\end{array}$} & ERCC2 (XPD) & $\begin{array}{l}\text { ERCC Excision } \\
\text { Repair } 2\end{array}$ & $\begin{array}{l}\text { Part of } \\
\text { transcriptional } \\
\text { initiation factor } \\
(\mathrm{TFIIH})\end{array}$ & $\begin{array}{l}\text { Involved in } \\
\text { transcription-coupled } \\
\text { nucleotide excision } \\
\text { repair }\end{array}$ & $\begin{array}{l}\text { Muations leading to } \\
\text { inactivation }\end{array}$ & $\begin{array}{l}\text { Point mutation } \\
\text { accumulation. } \\
\text { Vulnerability to cisplatin } \\
\text { chemotherapy. }\end{array}$ & $\begin{array}{l}\text { Kim et al., } 2016 \\
\text { Liu et al., } 2016\end{array}$ \\
\hline & ATM & $\begin{array}{l}\text { Ataxia telangiectasia } \\
\text { mutated }\end{array}$ & $\begin{array}{l}\text { Serine/threonine } \\
\text { protein kinase }\end{array}$ & $\begin{array}{l}\text { Initiates DNA damage } \\
\text { checkpoint activations } \\
\text { leading to cell cycle } \\
\text { arrest, DNA repair or } \\
\text { apoptosis }\end{array}$ & $\begin{array}{l}\text { High expression level } \\
\text { or mutations }\end{array}$ & \multirow{2}{*}{$\begin{array}{l}\text { Mutations accumulation. } \\
\text { Promotes proliferation. } \\
\text { Radiotherapy resistance. }\end{array}$} & He et al., 2017 \\
\hline & RB1 & $\begin{array}{l}\text { Retinoblastoma- } \\
\text { associated } \\
\text { protein }\end{array}$ & tumor suppressor & $\begin{array}{l}\text { Key cell division } \\
\text { regulator }\end{array}$ & Mutations & & Yin et al., 2018 \\
\hline & APOBEC & $\begin{array}{l}\text { Apolipoprotein B } \\
\text { mRNA editing } \\
\text { enzyme, catalytic } \\
\text { polypeptide-like }\end{array}$ & Cytidine deaminase & Regulatory protein & High expression level & $\begin{array}{l}\text { Mutations accumulation in } \\
\text { DNA damage response and } \\
\text { chromatin regulatory genes }\end{array}$ & $\begin{array}{l}\text { Glaser et al., } 2018 \\
\text { Jarvis et al., } 2018 \\
\text { Shi et al., } 2019\end{array}$ \\
\hline \multirow[t]{3}{*}{$\begin{array}{l}\text { Chromatin } \\
\text { modifying }\end{array}$} & KDM6A (UTX) & $\begin{array}{l}\text { Lysine-specific } \\
\text { demethylase 6A }\end{array}$ & Specific demethylase & $\begin{array}{l}\text { Transcriptional } \\
\text { regulation at promoters } \\
\text { and enhancers }\end{array}$ & $\begin{array}{l}\text { Mutations } \\
\text { Loss of function }\end{array}$ & $\begin{array}{l}\text { Promotes M2 macrophages } \\
\text { polarization increasing } \\
\text { cancer stem cells via } \\
\text { cytokines }\end{array}$ & $\begin{array}{l}\text { Hurst et al., } 2017 \\
\text { Nickerson et al., } 2014 \\
\text { Kaneko et al., } 2018 \\
\text { Kobatake et al., } 2020\end{array}$ \\
\hline & ARID1A & $\begin{array}{l}\text { AT-rich interactive } \\
\text { domain-containing } \\
\text { protein } 1 \mathrm{~A}\end{array}$ & $\begin{array}{l}\text { Part of SWI/SNF } \\
\text { family, Helicase and } \\
\text { ATPase activities }\end{array}$ & $\begin{array}{l}\text { Essential for } \\
\text { transcriptional activation } \\
\text { of genes normally } \\
\text { repressed by chromatin }\end{array}$ & $\begin{array}{l}\text { Mutations } \\
\text { Loss of function }\end{array}$ & $\begin{array}{l}\text { Involved in granting BC } \\
\text { non-stem cells the capability } \\
\text { of self-renewal. }\end{array}$ & $\begin{array}{l}\text { Balbas- } \\
\text { Martinez et al., } 2013 \\
\text { Li et al., } 2016 \\
\text { Yang et al., } 2016\end{array}$ \\
\hline & BAP1 & $\begin{array}{l}\text { BRCA1 associated } \\
\text { protein-1 }\end{array}$ & Deubiquitinase & $\begin{array}{l}\text { Involved in } \\
\text { transcription-coupled } \\
\text { nucleotide excision } \\
\text { repair }\end{array}$ & $\begin{array}{l}\text { Mutations } \\
\text { Loss of function }\end{array}$ & BRCA pathway alteration & $\begin{array}{l}\text { Nickerson et al., } 2014 \\
\text { Lin et al., } 2017 \\
\text { Tech et al., } 2020\end{array}$ \\
\hline
\end{tabular}


Table 1. Cont.

\begin{tabular}{|c|c|c|c|c|c|c|c|}
\hline Pathway & Altered Genes & Denomination & Activity & Fonction & $\begin{array}{l}\text { Status in Bladder } \\
\text { Cancer }\end{array}$ & $\begin{array}{c}\text { Alterations Consequences } \\
\text { in BC/Remarks }\end{array}$ & Publications \\
\hline \multirow{8}{*}{$\begin{array}{l}\text { Signaling } \\
\text { pathways }\end{array}$} & \multicolumn{2}{|c|}{ KRAS/HRAS/NRAS } & $\begin{array}{l}\text { GTP-binding } \\
\text { proteins part of } \\
\text { RTK/Ras pathway }\end{array}$ & $\begin{array}{l}\text { Involved in transducing } \\
\text { signal to regulate cell } \\
\text { proliferation, survival } \\
\text { and differenciation }\end{array}$ & $\begin{array}{l}\text { Mutations } \\
\text { Gain of function } \\
\text { Loss of function }\end{array}$ & $\begin{array}{l}\text { Hyperproliferative } \\
\text { development disorders }\end{array}$ & Wu et al., 2015 \\
\hline & FGFR3 & $\begin{array}{l}\text { Fibroblast growth } \\
\text { factor receptor } 3\end{array}$ & $\begin{array}{l}\text { Part of the fibroblast } \\
\text { growth factor } \\
\text { receptor family }\end{array}$ & Involved in bone growth & $\begin{array}{l}\text { MutationsGain of } \\
\text { expression }\end{array}$ & $\begin{array}{l}\text { Common feature of } \\
\text { low-grade BC }\end{array}$ & $\begin{array}{l}\text { The cancer genome } \\
\text { atlas research } \\
\text { network, } 2014 \\
\text { Akanksha and } \\
\text { Sandhya, } 2019 \\
\text { Wu et al., } 2015\end{array}$ \\
\hline & $\begin{array}{l}\text { PIK3CA/Akt/ } \\
\text { mTOR }\end{array}$ & $\begin{array}{l}\text { Phosphatidylinositol } \\
3 \mathrm{ki}- \\
\text { nase/Akt/mechanistic } \\
\text { target of rapamycin }\end{array}$ & $\begin{array}{l}\text { Intracellular } \\
\text { signaling pathway }\end{array}$ & $\begin{array}{l}\text { Involved in cell cycle } \\
\text { regulation }\end{array}$ & $\begin{array}{l}\text { Mutations } \\
\text { Gain of function } \\
\text { Loss of function }\end{array}$ & $\begin{array}{l}\text { Involved in tumor growth } \\
\text { and angiogenesis }\end{array}$ & $\begin{array}{l}\text { Ching and Hansel, } \\
2010\end{array}$ \\
\hline & TSC1/Hsp90 & $\begin{array}{l}\text { Tuberous sclerosis } \\
1 / \text { Heat shock protein } \\
90\end{array}$ & $\begin{array}{l}\text { Co-chaperone and } \\
\text { chaperone proteins }\end{array}$ & $\begin{array}{l}\text { TSC1 inhibits Hsp90 } \\
\text { activity and regulates } \\
\text { mTORC1 } \\
\text { Hsp90 help for protein } \\
\text { folding }\end{array}$ & $\begin{array}{l}\text { Chr9 deletion } \\
\text { Loss of function }\end{array}$ & & $\begin{array}{l}\text { Hornigold et al., } 1999 \\
\text { Woodford et al., } 2019 \\
\text { Knowles et al., } 2003 \\
\text { Guo et al., } 2013\end{array}$ \\
\hline & UPK1B & Uroplakin 1B & $\begin{array}{l}\text { Cell surface protein } \\
\text { mediating signal } \\
\text { transduction }\end{array}$ & $\begin{array}{l}\text { Involved in cell } \\
\text { development, activation } \\
\text { and growth }\end{array}$ & Upregulation & $\begin{array}{l}\text { Promotes proliferation, } \\
\text { invasion and migartion of } \\
\text { cancerous cells }\end{array}$ & Wang et al., 2018 \\
\hline & IGFBP5 & $\begin{array}{l}\text { Insulin-like growth } \\
\text { factor-binding } \\
\text { protein } 5\end{array}$ & Transport protein & $\begin{array}{l}\text { Transports IGF1 (Insulin } \\
\text { like growth factor 1) }\end{array}$ & Overexpression & & $\begin{array}{l}\text { Liang et al., } 2013 \\
\text { Neuzillet et al., } 2017\end{array}$ \\
\hline & ERBB2 & $\begin{array}{l}\text { Erythroblastic } \\
\text { oncogene-B2 receptor } \\
\text { tyrosine kinase } 2\end{array}$ & $\begin{array}{l}\text { Memeber of the } \\
\text { human epidermal } \\
\text { growth factor } \\
\text { receptor family }\end{array}$ & $\begin{array}{l}\text { promotes cell } \\
\text { proliferation }\end{array}$ & $\begin{array}{l}\text { Mutations } \\
\text { Overexpression }\end{array}$ & $\begin{array}{l}\text { Linked to development and } \\
\text { progression of cancers, } \\
\text { metastasis }\end{array}$ & $\begin{array}{l}\text { Groenendijk et al., } \\
2015 \\
\text { Yoshida et al., } 2019\end{array}$ \\
\hline & NID2 & Nidogen-2 & Basal lamina protein & $\begin{array}{l}\text { Plays a role during late } \\
\text { embryonic development }\end{array}$ & $\begin{array}{l}\text { Methylation status } \\
\text { change }\end{array}$ & $\begin{array}{l}\text { Important for BC } \\
\text { development but } \\
\text { mechanism not clear yet }\end{array}$ & $\begin{array}{l}\text { Fantony et al., } 2015 \\
\text { Fantony et al., } 2017\end{array}$ \\
\hline
\end{tabular}


Table 1. Cont.

\begin{tabular}{|c|c|c|c|c|c|c|c|}
\hline Pathway & Altered Genes & Denomination & Activity & Fonction & $\begin{array}{l}\text { Status in Bladder } \\
\text { Cancer }\end{array}$ & $\begin{array}{l}\text { Alterations Consequences } \\
\text { in BC/Remarks }\end{array}$ & Publications \\
\hline \multirow{3}{*}{$\begin{array}{l}\text { Post- } \\
\text { translational } \\
\text { modification }\end{array}$} & MDM2 & $\begin{array}{l}\text { Murine double } \\
\text { minute } 2\end{array}$ & E3 ubiquitin ligase & $\begin{array}{l}\text { Responsible for } \mathrm{p} 53 \\
\text { regulation }\end{array}$ & $\begin{array}{l}\text { Mutations } \\
\text { SNP at position } 309\end{array}$ & & $\begin{array}{l}\text { Gangwar and Devi } \\
\text { Mittal, } 2010 \\
\text { Xie et al., } 2015 \\
\text { Horikawa et al., } 2008\end{array}$ \\
\hline & CDK1 & $\begin{array}{l}\text { Cyclin-dependent } \\
\text { kinase } 1\end{array}$ & $\begin{array}{l}\text { Serine/threonine } \\
\text { kinase }\end{array}$ & $\begin{array}{l}\text { Key player in cell cycle } \\
\text { regulation by allowing } \\
\text { cell cycle progression }\end{array}$ & Overexpression & $\begin{array}{l}\text { Promotes proliferation, } \\
\text { invasion and self-renewal }\end{array}$ & $\begin{array}{l}\text { Tian et al., } 2018 \\
\text { Heo et al., } 2020\end{array}$ \\
\hline & AURKA & Aurora kinase A & $\begin{array}{l}\text { Serine/threonine } \\
\text { kinase }\end{array}$ & $\begin{array}{l}\text { Important for cell } \\
\text { proliferation }\end{array}$ & Overexpression & $\begin{array}{l}\text { Induces centrosome } \\
\text { amplification, chromosome } \\
\text { missegregation, aneuploidy } \\
\text { and stimulates cell } \\
\text { proliferation and invasion }\end{array}$ & $\begin{array}{l}\text { Park et al., } 2008 \\
\text { Mobley et al., } 2017 \\
\text { Guo et al., } 2018\end{array}$ \\
\hline \multirow{5}{*}{$\begin{array}{l}\text { Transcription } \\
\text { factor }\end{array}$} & EOMES & Eomesodermin & Transcription factor & $\begin{array}{l}\text { Important for } \\
\text { development and } \\
\text { immunity }\end{array}$ & Hypermethylation & $\begin{array}{l}\text { Important for BC } \\
\text { development but } \\
\text { mechanism not clear yet }\end{array}$ & Reinert et al., 2012 \\
\hline & POU4F2 & $\begin{array}{l}\text { POU domain, class } 4 \text {, } \\
\text { transcription factor } 2\end{array}$ & Transcription factor & $\begin{array}{l}\text { Involved in maintaining } \\
\text { visual system neurons }\end{array}$ & $\begin{array}{l}\text { Hyper or } \\
\text { Hypomethylation }\end{array}$ & $\begin{array}{l}\text { Important for BC } \\
\text { development but } \\
\text { mechanism not clear yet }\end{array}$ & $\begin{array}{l}\text { Reinert et al., } 2012 \\
\text { Wang et al., } 2015\end{array}$ \\
\hline & RUNX3 & $\begin{array}{l}\text { Runt-related } \\
\text { transcription factor } 3\end{array}$ & Transcription factor & $\begin{array}{l}\text { modulate the } \\
\text { transcription of their } \\
\text { target genes }\end{array}$ & $\begin{array}{l}\text { Deleted or silenced } \\
\text { due to } \\
\text { hypermethylation or } \\
\text { mutations }\end{array}$ & & $\begin{array}{l}\text { Kim et al., } 2005 \\
\text { Wilff et al., } 2008 \\
\text { Zhang et al., } 2008 \\
\text { Yan et al., } 2012\end{array}$ \\
\hline & TP53 & Tumor protein 53 & Transcription factor & $\begin{array}{l}\text { Involved in cell cycle } \\
\text { regulation, autophagy } \\
\text { and apoptosis }\end{array}$ & Mutations & & $\begin{array}{l}\text { Pandith et al., } 2010 \\
\text { Hoffman- } \\
\text { Censits et al., } 2019 \\
\text { Horikawa et al., } 2008\end{array}$ \\
\hline & TERTp & $\begin{array}{l}\text { Telomeras reverse } \\
\text { transcriptase } \\
\text { promoter }\end{array}$ & $\begin{array}{l}\text { Promoter for a } \\
\text { RNA-dependent } \\
\text { telomerase }\end{array}$ & Lengthens telomeres & $\begin{array}{l}\text { Mutations } \\
\text { Loss of function }\end{array}$ & & $\begin{array}{l}\text { Batista et al., } 2020 \\
\text { Nickerson et al., } 2014\end{array}$ \\
\hline
\end{tabular}


Table 1. Cont.

\begin{tabular}{|c|c|c|c|c|c|c|c|}
\hline Pathway & Altered Genes & Denomination & Activity & Fonction & $\begin{array}{l}\text { Status in Bladder } \\
\text { Cancer }\end{array}$ & $\begin{array}{l}\text { Alterations Consequences } \\
\text { in BC/Remarks }\end{array}$ & Publications \\
\hline \multirow[t]{3}{*}{ Growth factor } & IGF2 & $\begin{array}{l}\text { Insulin-like growth } \\
\text { factor } 2\end{array}$ & Hormone & $\begin{array}{l}\text { Growth promoting } \\
\text { hormone indispensable } \\
\text { during gestation } \\
\text { Involved in } \\
\text { carbohydrates } \\
\text { metabolism }\end{array}$ & $\begin{array}{l}\text { Overexpression } \\
\text { Hyper or } \\
\text { Hypomethylation }\end{array}$ & $\begin{array}{l}\text { Important for BC } \\
\text { development but } \\
\text { mechanism not clear yet }\end{array}$ & $\begin{array}{l}\text { Byun et al., } 2007 \\
\text { Chen et al., } 2013\end{array}$ \\
\hline & ANXA10 & Annexin 10 & $\begin{array}{l}\text { calcium-dependent } \\
\text { phospholipid } \\
\text { binding }\end{array}$ & $\begin{array}{l}\text { Involved in cellular } \\
\text { growth and in signal } \\
\text { transduction }\end{array}$ & Lower expression & $\begin{array}{l}\text { Important for BC } \\
\text { development but } \\
\text { mechanism not clear yet }\end{array}$ & $\begin{array}{l}\text { Munksgaard et al., } \\
2011\end{array}$ \\
\hline & NEGF2 & $\begin{array}{l}\text { neurite } \\
\text { growth-promoting } \\
\text { factor } 2\end{array}$ & $\begin{array}{l}\text { Basic } \\
\text { heparin-binding } \\
\text { growth factor }\end{array}$ & $\begin{array}{l}\text { Involved in cell } \\
\text { proliferation, cell } \\
\text { migration and survival }\end{array}$ & Overexpression & $\begin{array}{l}\text { Involved in cell proliferation, } \\
\text { cell migration and } \\
\text { angiogenesis }\end{array}$ & $\begin{array}{l}\text { Hunter et al, } 2000 \\
\text { Sakamoto et al., } 2012 \\
\text { Jones et al., } 2014\end{array}$ \\
\hline \multirow{2}{*}{$\begin{array}{l}\text { Bladder cancer } \\
\text { antigen }\end{array}$} & BLCA1/BLCA4 & $\begin{array}{l}\text { Bladder } \\
\text { cancer-specific } \\
\text { nuclear matrix } \\
\text { protein }\end{array}$ & $\begin{array}{l}\text { nuclear matrix } \\
\text { protein }\end{array}$ & $\begin{array}{l}\text { increases the levels of } \\
\text { IL- } 1 \alpha, \text { IL- } 8 \text { and } \\
\text { thrombomodulin }\end{array}$ & expressed only un BC & $\begin{array}{l}\text { Promote tumor cell } \\
\text { proliferation, survival and } \\
\text { angiogenesis }\end{array}$ & Schawlb et al., 1993 \\
\hline & $\begin{array}{l}\text { M344 and } \\
\text { LDQ1053 } \\
\text { tumor- } \\
\text { associated } \\
\text { antigens: } \\
\text { MAUB }\end{array}$ & $\begin{array}{l}\text { mucin antigen of the } \\
\text { urinary bladder }\end{array}$ & $\begin{array}{l}\text { high molecular } \\
\text { weight glycoproteins }\end{array}$ & $\begin{array}{l}\text { cell signaling, cell } \\
\text { adhesions, } \\
\text { differentiation of } \\
\text { epithelial cells and } \\
\text { immune response }\end{array}$ & $\begin{array}{l}\text { aberrant regulation } \\
\text { of mucin gene } \\
\text { expression or aber- } \\
\text { rantglycosylation of } \\
\text { the gene product }\end{array}$ & $\begin{array}{l}\text { Aggressive biological } \\
\text { behavior }\end{array}$ & $\begin{array}{l}\text { Bergeron et al., } 1996 \\
\text { Moniaux et al., } 2001 \\
\text { Rachagani et al., } 2009\end{array}$ \\
\hline \multirow[b]{2}{*}{$\begin{array}{l}\text { Extracellular } \\
\text { compartement }\end{array}$} & HA & Hyaluronic acid & $\begin{array}{l}\text { Nonsulfated } \\
\text { glycosaminoglycan }\end{array}$ & $\begin{array}{l}\text { Component of tissue } \\
\text { matrix and tissue fluids }\end{array}$ & $\begin{array}{l}\text { Absent form } \\
\text { urothelial cells }\end{array}$ & & $\begin{array}{l}\text { Lokeshwar et al., } \\
2000\end{array}$ \\
\hline & hCFHrp & $\begin{array}{l}\text { Human complement } \\
\text { factor H-related } \\
\text { protein }\end{array}$ & $\begin{array}{l}\text { Member of the } \\
\text { complement factor } \mathrm{H} \\
\text { family }\end{array}$ & Regulates factor $\mathrm{H}$ & $\begin{array}{l}\text { Absent form } \\
\text { urothelial cells }\end{array}$ & $\begin{array}{l}\text { Promote growth and host } \\
\text { immune system escaping }\end{array}$ & $\begin{array}{l}\text { Kinders et al., } 1998 \\
\text { Raitanen et al., } 2001\end{array}$ \\
\hline
\end{tabular}


Table 1. Cont.

\begin{tabular}{|c|c|c|c|c|c|c|c|}
\hline Pathway & Altered Genes & Denomination & Activity & Fonction & $\begin{array}{l}\text { Status in Bladder } \\
\text { Cancer }\end{array}$ & $\begin{array}{c}\text { Alterations Consequences } \\
\text { in BC/Remarks }\end{array}$ & Publications \\
\hline & CD15s & $\begin{array}{l}\text { Lewis X } \\
\text { antigen/Sialyl } \\
\text { LewisX } \\
\text { (sLeX)/stage-specific } \\
\text { embryonic antigen } 1 \\
\text { (SSEA-1) }\end{array}$ & $\begin{array}{l}\text { surface glycan/Blood } \\
\text { group antigen }\end{array}$ & $\begin{array}{l}\text { cell-to-cell recognition } \\
\text { processes and } \\
\text { fettilization }\end{array}$ & $\begin{array}{l}\text { Absent form } \\
\text { urothelial cells }\end{array}$ & $\begin{array}{l}\text { Leukocyte adhesion } \\
\text { deficiency }\end{array}$ & $\begin{array}{l}\text { Mourant et al., } 1946 \\
\text { Itzkowitz et al., } 1986 \\
\text { Pode et al., } 1998\end{array}$ \\
\hline & Fibrin/Fibrinogen & Fibrin/Fibrinogen & $\begin{array}{l}\text { fibrous, non-globular } \\
\text { protein }\end{array}$ & clotting of blood & overexpression & & Schmetter et al., 1997 \\
\hline & EVs & Extracellular vesicles & $\begin{array}{l}\text { lipid } \\
\text { bilayer-delimited } \\
\text { particles }\end{array}$ & $\begin{array}{l}\text { proteins, nucleic acids, } \\
\text { lipids, metabolites, and } \\
\text { even organelles transport } \\
\text { from the parent cell }\end{array}$ & & $\begin{array}{l}\text { Communication between } \\
\text { tumor cells and stromal cells } \\
\text { and local tumor progression, } \\
\text { metastatic spread and the } \\
\text { emergence of drug resistance }\end{array}$ & $\begin{array}{l}\text { Lin et al., } 2016 \\
\text { Silvers et al., } 2017\end{array}$ \\
\hline Cell structure & CK & Cytokeratins & $\begin{array}{l}\text { Intermediate } \\
\text { filament proteins }\end{array}$ & $\begin{array}{l}\text { Helps to resist to } \\
\text { mechanical stress }\end{array}$ & Overexpression & $\begin{array}{l}\text { Aberrant differentiation in } \\
\text { the process of urothelial } \\
\text { carcinogenesis and poor } \\
\text { prognosis }\end{array}$ & $\begin{array}{l}\text { Björklund et al., } 1957 \\
\text { Lüning et al., } 1980\end{array}$ \\
\hline $\begin{array}{l}\text { Nuclear } \\
\text { mitotic } \\
\text { apparatus }\end{array}$ & NMP22 & $\begin{array}{l}\text { Nuclear matrix } \\
\text { protein } 22\end{array}$ & nulcear protein & $\begin{array}{l}\text { Important role in mitosis } \\
\text { regulation }\end{array}$ & Overexpression & $\begin{array}{l}\text { NMP22 is released from cells } \\
\text { during apoptosis }\end{array}$ & $\begin{array}{l}\text { Miyanaga et al., } 1999 \\
\text { Bibbo et al., } 2008 \\
\text { Balci et al., } 2015\end{array}$ \\
\hline $\begin{array}{l}\text { Apoptosis } \\
\text { inhibitor }\end{array}$ & BIRC5 & $\begin{array}{l}\text { Baculovirus IAP } \\
\text { repeat-containing } \\
\text { protein } 5 \text { or Survivin }\end{array}$ & $\begin{array}{l}\text { Member of the } \\
\text { inhibitor of apoptosis } \\
\text { protein (IAP) }\end{array}$ & $\begin{array}{l}\text { Important only during } \\
\text { fetal development }\end{array}$ & Overexpression & cell survive & $\begin{array}{l}\text { Ambrosini et al., } 1997 \\
\text { Li et al., } 1998 \\
\text { Li et al., } 1999 \\
\text { Altieri et al., } 1999\end{array}$ \\
\hline $\begin{array}{l}\text { Nuclear } \\
\text { import/export }\end{array}$ & KPNA2 & Karyopherin alpha 2 & $\begin{array}{l}\text { Member of the } \\
\text { karyopherin family }\end{array}$ & $\begin{array}{l}\text { Involved in cargo } \\
\text { localization regulation }\end{array}$ & Overexpression & $\begin{array}{l}\text { Increases proliferation, } \\
\text { migration and invasion } \\
\text { ability }\end{array}$ & Shi et al., 2020 \\
\hline
\end{tabular}




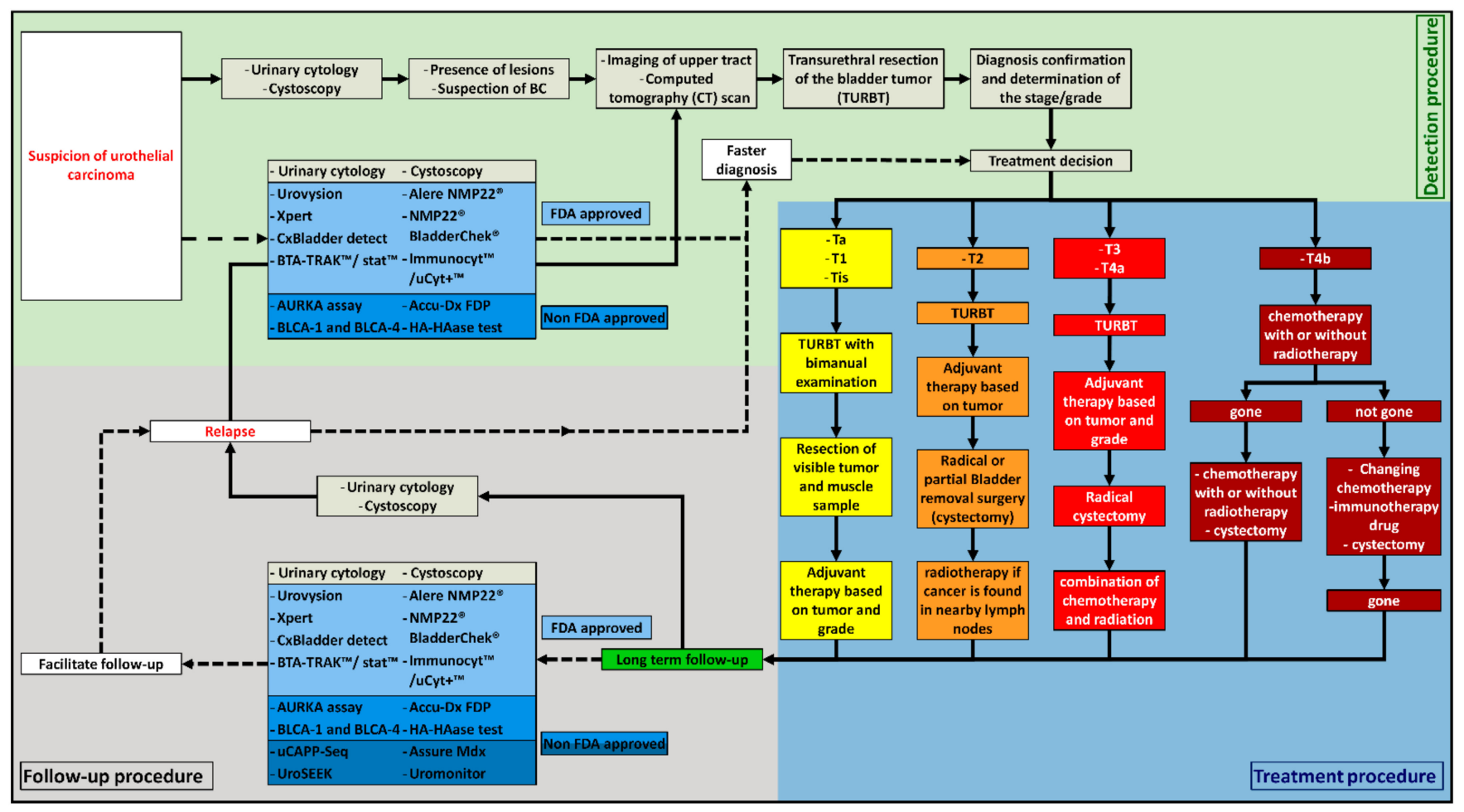

Figure 2. The different ways of detection, diagnosis, treatment, and follow-up of BC, depending on the clinical situation. - Classical routine used by the clinicians nowadays; -- - - - : new methods that can be used by the clinicians nowadays.

Cystoscopy is the gold standard for the detection of $\mathrm{BC}$. It gives information about the number, localization, aspect and size of the tumor(s). It is systematically performed when there is a suspicion of $\mathrm{BC}$ with urine cytology [9]. This method has a sound sensitivity (68.3 to $100 \%$ ) but can give false negative result (due to operator error or the difficulty of finding the tumor because of its small size at the carcinoma in situ stage). It also has a good specificity (57 to 97\%) [10]. Cystoscopy is an endoscopic procedure used to look inside the bladder. It is an invasive assay and causes patient discomfort, possible urinary tract infection, and anxiety [10-13].

A disadvantage of these two tests is their low efficiency for detecting BC at an early stage. Indeed, the detection of early stage $B C$ is a real issue nowadays. Early detection gives the patients a greater probability of being cured from $\mathrm{BC}$ and is cheaper to treat. Indeed, $\mathrm{BC}$ is an expensive cancer to treat and to survey in comparison with other cancers. Its cost fluctuates between USD 47,500 for distant BC to USD 14,300 during the 1st year after diagnosis, and can reach more than USD 172,000 for a long-term survivor [14]. Over the past years, many new tests have been developed in order to detect $B C$ earlier than with current cytology and cystoscopy, and to improve the specificity of $B C$ diagnosis. The aim of this review is to present $\mathrm{BC}$ diagnostic tests that are available and are being developed at the moment. The specificity and sensitivity of each test will be compared to cytology and cystoscopy results, and every positive or negative aspect will be highlighted to have a clear vision of what their use could bring to the field (the summarized information has been compiled in Supplementary Table S1).

\section{Urine Protein-Based Assays}

Lots of studies are being conducted to improve the diagnostic accuracy of urinary tests, both to create an alternative to urinary cytology and cystoscopy and to improve patients' follow-up. Numerous biomarkers have been found and some of these underwent clinical validation and approval. Urine has lots of advantages for biomarker detection. It 
is noninvasive, easy to handle, and more than one biomarker can be investigated at the same time. Indeed, lots of proteins or RNAs present in the urine already serve as markers of cellular dysfunctionality $[15,16]$.

\subsection{FDA-Approved}

\subsubsection{BTA-TRAK ${ }^{\mathrm{TM}}$ and BTA-STAT ${ }^{\mathrm{TM}}$}

BTA-TRAK ${ }^{\mathrm{TM}}$ and BTA-STAT ${ }^{\mathrm{TM}}$ are dosages of the Bladder tumor antigen (BTA), which is the human complement factor H-related protein (hCFHrp). hCFHrp plays a major role in alternative pathway regulator factor $\mathrm{H}$. This protein has played a role in the carcinogenesis by giving a selective growth advantage and an escape to the host immune system $[17,18]$. BTA-TRAK is a urine ELISA test and BTA-STAT ${ }^{\mathrm{TM}}$ is a quantitative point-of-care test. It has been shown that BTA-TRAK and BTA-STAT ${ }^{\mathrm{TM}}$ sensitivity are better than cytology (57-83\% vs. $37 \%$ respectively) [19-21]. However, their specificity is lower than urinary cytology due to false-positives (51-75\% vs. 99\%) [20], in particular, nontumor urinary tract diseases [22,23]. That is the reason why these tests are only used for patient follow-up in association with cytology [21]. They can also be detected in urine.

\subsubsection{NMP22 (Nuclear Matrix Protein 22) Protein Test}

Nuclear matrix protein 22 (NMP22) has an important role in the regulation of mitosis by regulating the distribution of chromatin to daughter cells, and is found in the nuclear matrix of all cell types [24]. NMP22 is highly expressed in bladder tumor cells and released from the nucleus after they die; it can be detected in the urine [25-27]. Two tests are available for the dosage of NMP22, an ELISA test (Alere NMP2 $2{ }^{\circledR}$ ) or a point-ofcare test (NMP22 BladderChek ${ }^{\circledR}$ ). The sensitivity of the Alere NMP22 ${ }^{\circledR}$ test and NMP22 BladderChek ${ }^{\circledR}$ test are higher than cytology alone $(68 \%$ and $65 \%$, respectively, vs. $37 \%$ for the cytology [28]. The grade of the tumor plays an important role in the specificity of the test $[29,30]$. However, the specificity is still lower than cytology- $79 \%$ for Alere NMP22 ${ }^{\circledR}$ vs $95 \%$ for cytology [28]. Unfortunately, the constitutive presence of NMP22 in urothelial cells can induce a false-positive and impair diagnostic specificity [21,22,30]. NMP22 level is not used for the first diagnostic but it helps for the follow up, since it has shown a higher sensitivity than cytology for the low-risk group [31]. Finally, NMP22 BladderChek ${ }^{\circledR}$ is a test which is easy to perform; it gives results in $30 \mathrm{~min}$, in contrast to Alere NMP22 ${ }^{\circledR}$, which needs to be performed in the laboratory.2.1.3. Immunocyt ${ }^{\mathrm{TM}} / \mathrm{uCyt}+{ }^{\mathrm{TM}}$.

ImmunoCyt/uCyt+ is an immunocytochemical test targeting two antigens and was developed by Fradet and Lockhard in 1997. The first antigen is a superficial bladder cancer-associated sialylated epitope expressed on a heterogeneous group of glycoproteins in the membrane; more precisely, a glycoform of the carcinoembryonic antigen (CEA). This CEA glycoform is a $200 \mathrm{kDa}$ membrane glycoprotein anchored to the membrane via a glycosylphosphatidylinositol link and is highly glycosylated. This glycoprotein is observed in tumor cells only, and preferentially in superficial bladder tumors [32-34]. This antigen is targeted by the 19A211 antibody [33]. The second antigen is a secreted high-molecularmass mucin-like, called mucin antigen of the urinary bladder (MAUB) [35]. It is secreted by mucosae and some exocrine glands [34-37]. This MAUB is targeted by M344 and LDQ1053 antibodies.

Studies have shown that ImmunoCyt/uCyt+ alone has a sensitivity ranging from $38.5 \%$ to $92.1 \%$ across all grades and risk categories, which is higher than cytology (from $23 \%$ to $84.6 \%$ ). However, the specificity is better for cytology than for ImmunoCyt/uCyt+, with a range from $62 \%$ to $84.2 \%$ vs. $79.7 \%$ to $99.4 \%$ for cytology. Nevertheless, it has been shown that when cytology tests and ImmunoCyt/uCyt+ are used together, sensitivity improves by at least $15 \%$, ranging between $53.8 \%$ and $94.1 \%$ [38]. Moreover, the sensitivity for low-grade tumor increased from $8.3 \%$, for cytology alone, to $79.3 \%$ with a combination of both diagnostics [39]. They also showed that the sensitivity for high-grade was improved, with a sensitivity by $75.3 \%$, for cytology alone, and $98.9 \%$ for the combination. Unfortunately, the specificity of the combination is still lower than cytology alone (ranging 
from $61 \%$ to $80.7 \%$ ) [40,41] but better than ImmunoCyt/uCyt+ alone. In conclusion, this test is useful for improving overall sensitivity when combined with cytology for all grades of $\mathrm{BC}$.

\subsection{Non-FDA-Approved}

\subsubsection{Cytokeratins}

The first potential role of cytokeratins as tumor markers for epithelial cancer cells has been shown by Björklund B. and Björklund V, in 1957, with the tissue polypeptide antigen (TPA) [42]. TPA is present in the proteolytic fragments of CKs 8, 18 and 19; these fragments are released into body fluids, such as urine and serum, as a sign of cell death [43]. It has been shown that the concentration of the antigen is higher in patients with tumors [44]. Since the discovery of the high level of $\mathrm{CKs}$ in $\mathrm{BC}$, several commercially available tumor marker tests have been developed, such as the TPA, tissue polypeptide-specific antigen (TPS) for CKs 8 and 18, tissue polypeptide cytokeratin antigen (TPACYK), and the cytokeratin fragment of CKs 8 and 19 (CYFRA 21-1) [45]. However, since 2016, a new test to detect cytokeratins has been specifically developed for the diagnosis of $\mathrm{BC}$, the UBC ${ }^{\circledR}$ Rapid Test (Concile GmbH, Freiburg, Germany). This test is now the most commonly used for the detection of cytokeratins. It is a point-of-care test. Two tests are available and both measure fragments of cytokeratins 8 and 18; one is a quantitative measurement and the other is a qualitative measurement $[46,47]$. These cytokeratins are soluble in urine and can be detected quantitatively with monoclonal antibodies using an enzyme-linked immunosorbent assay (ELISA) [48]. The qualitative and quantitative UBC ${ }^{\circledR}$ Rapid Test had a better sensitivity than cytology alone ( $61.3 \%$ and $64.5 \%)$, but still a lower specificity $(77.3 \%$ and $81.8 \%)$.

However, it has been shown that the combination of the UBC ${ }^{\circledR}$ Rapid Test with cytology results in a higher overall sensitivity (77.4\%). In contrast with cytology alone, sensitivity increased from $21.4 \%$ to $50 \%$ for detecting low-grade tumors, and from $43.8 \%$ to $100 \%$ for high-grade cancers, albeit with a reduced specificity from $100 \%$ to $77.3 \%$ [ 49 ].

\subsubsection{Lewis $X$ Antigen}

Carbohydrate antigen 3-fucosyl-N-acetyllactosamine, also known as Lewis $\mathrm{X}$, is a blood group antigen belonging to the Lewis system. It was first described by Mourant [50]. It is localized on the surface of cells, such as granulocytes, kidney tubules, and gastrointestinal epithelia [51]. This antigen is normally absent from the urothelial cells in adults, but is expressed by more than $90 \%$ of papilloma and transitional cell carcinomas, irrespective of the tumor grade or stage of the $\mathrm{BC}$ [52]. This test works with a monoclonal anti-Lewis $X$ antibody (P12) directed against the Lewis X determinant [53]. Only old studies have been performed with the use of this marker, and showed a median sensitivity of $75 \%$ and a median specificity of $85 \%$ [52,54]. Due to the small number of studies, it is still unknown if this biomarker is efficient.

\subsubsection{Survivin}

Survivin, also known as baculovirus IAP repeat-containing protein 5 (BIRC5) and apoptosis inhibitor 4 (API4), is a member of the inhibitor of apoptosis protein (IAP) family [55]. Survivin participates in the suppression of apoptosis and is a regulator of the cell division [56-58]. Survivin is normally expressed during embryonic and fetal development. It is completely undetectable in normal adult tissue, but a vast majority of tumors express Survivin mRNA and protein at high levels. It can be found inside (cytoplasm, nucleus, and mitochondria) or outside (extracellular space through vesicles) the cell [55,59-62].

In BC, Survivin expression has been observed by immunohistochemistry and may negatively impact the recurrence of the disease [63]. Actually, studies have shown that Survivin has a real interest, with a sensitivity of $100 \%$ and a specificity of $80 \%$ to $90 \%$ [64,65], which means that this marker could be a good test to help in the detection of BC. 


\subsubsection{Hyaluronic Acid-Hyaluronidase Test (HA-HAase Test)}

Hyaluronic Acid (HA) is a nonsulfated glycosaminoglycan and a component of the extracellular matrix in solid and fluid tissues [66]. The concentration of HA is elevated in several cancers and it has been shown that levels of HA are three to five-fold higher in bladder tumor tissue extracts when compared with normal bladder extracts [67]. Moreover, the expression of the hyaluronidases (HAase) (the enzymes capable of degrading the HA) is also highly expressed in BC tissue when compared with normal bladder extracts [68]. Furthermore, it is also shown that levels of HAase are correlated with the tumor grade. This increase of HAase plays a role in the invasive potential of $B C$ [69]. The HA-HAase test is comprised of two ELISA-like assays: the HA test (dosing the HA) and the HAase test (dosing the HAase). The HA and HAase assays use a biotinylated HA-binding protein (HABP) and an avidin-biotin system for detection $[22,66,70,71]$. A recent meta-analyze showed that the sensitivity of the test is $90.8 \%$ for all tumors, with a specificity of $82.5 \%[66,72,73]$. These results suggested that HA-HAase are good biomarkers for the diagnosis of BC.

\subsubsection{BLCA-1 and BLCA-4}

Bladder Cancer-Specific Nuclear Matrix Proteins (BLCA) are proteins only found in BC. It has been shown that these proteins are associated with tumor cell proliferation, survival, and angiogenesis [74,75]. BLCA-4 is one of the most abundant of this family of six proteins (BLCA-1 to -6). They have been detected in the entire bladder, including the tumor and normal adjacent areas, of individuals who have bladder cancer [74,75]. BLCA-1 is also one of the most abundant and has been shown to be significantly highly expressed in patients with $B C$ than in normal individuals; however, with no correlation with tumor grade. For BLCA-1, a preliminary study showed a sensitivity of $80 \%$ and specificity of $87 \%$, demonstrating the potential interest of a BLCA-1-based assays in diagnosis and surveillance of patients with BC [76]. BLCA-4 expression does not appear to be affected by tumor grade or various benign urologic disorders [77]. The protein level in urine was tested using ELISA. A pooled analysis estimated a sensitivity of $93 \%$ and a specificity of $97 \%$ for BC $[78,79]$.

Current studies suggest that BLCA- 1 and BCLA- 4 are promising markers in BC diagnostics. Nevertheless, more studies are needed to confirm that BCLA-1 and BLCA-4 are good markers for BC detection.

\subsubsection{Fibrin-Fibrinogen Degradation Product (FDP), the Accu-Dx FDP}

It has been shown that $\mathrm{BC}$ produces a high level of vascular endothelium growth factor (VEGF) [80]. VEGF increases the permeability of the tumor vessels, which leads to leakage of plasma and blood proteins, such as plasminogen and fibrinogen, and coagulation factors into the extracellular space. Coagulation factors rapidly transform fibrinogen into fibrin, which is secondarily degraded by plasmin into FDP [81]. Increased urine fibrin/FDP levels have been shown with the presence of BC [82]. Since the middle of the 1970s, the identification of FDP in urine has been evaluated as a diagnostic test for BC. The AccuDx FDP, a qualitative test, is a rapid immunoassay measuring FDP in the urine in a few minutes $[82,83]$. Studies have shown a sensitivity ranging from $52 \%$ to $83 \%$ and a specificity from $68 \%$ to $86 \%$. Due to a problem with technical stability during manufacturing, the marketing of the Accu-Dx FDP has been stopped [84].

\subsection{Developing Diagnostics}

\subsubsection{Tumor-Secreted Extracellular Vesicles (EVs)}

Recently, a small study identified 4 proteins as potential biomarker candidate proteins in EVs secreted by BC cell lines using mass spectrometry, which could be useful for diagnostics (HEXB, S100SA4, SND1 and EHD4) [85]. Moreover, using mass spectrometry, another study found 2 proteins to be possible diagnostic urinary EV biomarkers, $\alpha-1$ antitrypsin and $\mathrm{H} 2 \mathrm{~B} 1 \mathrm{~K}$ [86]. The authors showed that, when these proteins are combined for the detection of BC, they have a sensitivity of $62.7 \%$ and a specificity of $87.59 \%$. Another 
protein, the periostin present in urinary EVs, has been shown to be significantly higher in urinary EVs from patients with BC than healthy participants [87]. Periostin plays an important role in the invasion in BC. However, more data still need to be collected to evaluate the real efficiency of EV proteins as biomarkers, as not many studies have been performed, covering a small number of patient samples.

\subsubsection{Urinary Midkine Protein}

Midkine protein (MK), also known as neurite growth-promoting factor 2 (NEGF2), is a heparin-binding growth factor involved in several pathways, such as growth factor activities in cellular proliferation, survival, and migration. In addition to the growth factor activities, MK also plays a role in fibrinolysis, blood pressure, host defense, and other processes $[88,89]$. In adult physiological condition, MK is only detected in kidneys at a very low level [90]. In contrast, MK was demonstrated to be significantly upregulated in various human cancers, such as BC [91]. This observation has been correlated with previous studies, which described that the upregulation of $\mathrm{MK}$ is also observed in urine specimens of $\mathrm{BC}$ patients [92,93]. It has been shown that the expression of $\mathrm{MK}$ is correlated with a poor outcome in patients with invasive $B C$, with a higher concentration in urine in advanced stages of BC [94]. Unfortunately, a recent study showed that the dosage of the urinary MK is less efficient than a urinary cytology, with a sensitivity of $69.7 \%$ vs. $87.6 \%$ and a specificity of $77.9 \%$ vs. $87.7 \%$. The combination of dosages of the urinary MK with the urinary cytology improved the sensitivity to $93.3 \%$ with, as a counterpart, a reduction of the specificity to $66.2 \%$ [94]. Thus, urinary MK could potentially be suitable for the identification of patients with a high risk of BC.

\subsubsection{Liquid-Based Cytology (LBC) in BC and Quantitative Proteomic Analysis}

LBC is an innovative slide-making technique. It has been widely used for several cancers, such as cervical cancer, breast cancer, sputum cytology of lung cancer, and now, in BC. The LBC allows a better quality of the samples by reducing the time to make a sample slide, removing the nonurothelial cells and mucus in the urine, humidifying slides, and decreasing cell degeneration using a preservation solution. It also improves the microscopic analysis of the slides with a better background, a better cell dispersion, and with less atypical cells than in urinary cytology [95]. A recent meta-analysis shows that LBC has no significant sensitivity improvement when compared to a traditional urinary cytology, with a sensitivity of $58 \%$ and specificity of $96 \%$ [95]. But it was shown that LBC is more efficient in detecting malignant cells in comparison with urinary cytology (37.3\% vs. $25.3 \%)$ [96]. More studies are needed to evaluate if LBC is a good method to replace classical cytology. Finally, a recent study shows that LBC could be a useful tool to detect new clinical biomarkers [97]. The authors generated the first and largest in-depth quantitative proteomic analysis of BC using $\mathrm{LBC}$. They were able to detect a unique intracellular protein, the neuroblast differentiation-associated protein, AHNAK, with a different expression and localization between tumor and nontumor cells. However, further investigation is required to understand the importance of this protein.

\section{Urine DNA/RNA Based Assays}

Another way to diagnose cancer is to use DNA or RNA released or contained by malignant cells. One of the advantages of using DNA or RNA is that it can be amplified and can be used at early stages. Here, we are presenting tests that have been developed for $\mathrm{BC}$.

\subsection{Commercialized Urine DNA/RNA Tests}

\subsubsection{Urovysion}

Urovysion is a 4 target multicolor FISH-based test, developed in 2000, to detect $\mathrm{BC}$ in urine [98]. The probe set is composed of directly labeled DNA probes targeting pericentromeric regions of chromosomes 3 (CEP3), 7 (CEP7), and 17 (CEP17), as well as the 
9p21 locus (LSI 9p21) to quantify the homozygous deletion of the p16 tumor suppressor gene. A 4'-6-diamidino-2-phenylindole stain also allows the evaluation of atypical nuclear features; in fact, polysomic cells tend to have large and irregular nuclei. In their initial paper, Sokova et al., tested Urovysion in 21 BC patients and 9 healthy donors to determine the optimal set of FISH probes, and then in 179 patients, including 93 with BC history and 86 who were healthy, for validation [98]. They found a sensitivity of $84 \%$ and a specificity of $92 \%$. In another study, they compared the Xpert assay (see below) to the Urovysion assay on 239 patients with a history of $\mathrm{BC}$, and found a sensitivity of $74 \%$ ( $83 \%$ for high grade $\mathrm{BC}$ ) and a specificity of $80 \%$ [99]. Numerous publications have been released since then, mostly about trials to validate Urovysion use as a BC surveillance test. One study, published in 2007, followed 250 patients with BC for 23 months [100]. They compared Urovysion tests to cytology and found that Urovysion is more sensitive at detecting BC recurrence (74\% compared to $61 \%$ ). Another study, published in 2018, assessed the potential benefit of using two Urovysion tests 3 months apart onto specificity and sensitivity of this test for BC recurrence [101]. The authors tested this hypothesis in a cohort of more than 400 patients who had been treated by transurethral resection of bladder tumor for BC and diagnosed within 2 years. If, with the first tests (Urovysion and Cytology), a new tumor was found, the trial ended for them; if nothing was suspicious, then they underwent the same tests 3 months later. By using 2 Urovysion tests, BC recurrence detection was increased from $50 \%$ to $72 \%$, and $42 \%$ of low-grade $B C$ and $67 \%$ of high-grade $B C$ were detected against $0 \%$ and $11 \%$ using cytology.

Urovysion is a noninvasive test that allows the detection of BC, independent of specific mutations. This test is far more efficient for detecting $B C$ recurrence than cytology. However, one of the problems that can come out using Urovysion is that it can detect other types of cancer, such as kidney cancer, due to leakage of cells in the urine. Urovysion has also a high false-positive rate of $27.6 \%$ [101]. Thus, Urovysion may not replace cytology and cystoscopy for the initial detection of $\mathrm{BC}$; the two golden techniques are more efficient. That said, this assay could be used for the follow-up of BC patients. Despite the false-positive rate, the use of Urovysion, instead of cytology, could improve confidence with regard to detecting $\mathrm{BC}$ recurrence and diminish cystoscopy frequency, especially if two consecutive Urovysion tests are used. The Urovysion assay has been approved by the FDA in 2001.

\subsubsection{Xpert Bladder Cancer Monitor}

The Xpert bladder cancer monitor assay analyzes five mRNA targets (ABL1, CRH, IGF2, UPK1B, and ANXA10), frequently overexpressed in BC, using real-time-PCR (Polymerase Chain Reaction) $[49,99]$. ABL1 serves as a sample adequacy control to ensure the presence of human cells in the urine sample. The Xpert BC monitor is used as a kit. Briefly, cells are captured on a filter, lysed by sonication, and RNA is used for real time PCR. The Xpert bladder cancer monitor has first been compared to cystoscopy and cytology for the follow-up of 140 NMIBC patients [49]. In term of sensitivity, the Xpert assay reached $84 \%$ and cytology reached $33 \%$. For specificity, the Xpert assay reached $91 \%$ and cytology reached $94 \%$. The combination of both Xpert BC monitor and cytology did not enhance diagnostic performances. This test is more efficient in detecting $B C$ recurrence than cytology. However, it does not seem that the Xpert assay will replace cytology and cystoscopy for the initial detection of $\mathrm{BC}$; the two golden techniques are still more trusted and could cover more cancer types than the Xpert bladder cancer monitor, which focuses on only 5 mRNAs and is not representative of every BC type. However, for the follow-up of patients, Xpert assays could be used as replacements for cytology to improve confidence at detecting $B C$ recurrence and diminish cystoscopy frequency.

\subsubsection{CxBladder Detect}

The CxBladder detect assay is based on the quantification of 5 mRNA biomarkers found in urine. Four of these biomarkers (IGFBP5, HOXA13, MDK, and CDK1) are associated with growth and propagation of tumor tissue, whereas the fifth biomarker, CXCR2, is 
a marker of inflammation highly expressed in neutrophils. In this context, CXCR2 enables one to separate patients with BC from patients with inflammation alone [102,103]. In the initial study, 36 patients with no prior history of BC, 39 patients under surveillance for BC recurrence, and 77 patients with nonmalignant diseases were followed [102]. For low grade BC, a sensitivity of $47 \%$ was achieved and $100 \%$ was achieved for high grade BC. Another study compared the CxBladder assay and cytology [103]. They worked on 485 patients with gross hematuria, but without history of $\mathrm{BC}$, and obtained their voided urine before cystoscopy. They obtained a sensitivity of $82 \%$ for the CxBladder assay $(97 \%$ for high grade BC) against $56 \%$ for cytology. CxBladder specificity was $85 \%$ and $94 \%$ for cytology, showing a higher false-positive rate. Using the different markers, they can distinguish between lowand high-grade BC, with a sensitivity of $91 \%$ and a specificity of $90 \%$. CxBladder will not replace cystoscopy for the initial detection of $\mathrm{BC}$, but it could replace cytology because it is more efficient and makes it easier to separate low- and high-grade BC. Despite the falsepositive rate, the use of CxBladder in replacement of cytology could improve confidence at detecting BC and diminish cystoscopy frequency [104]. Darling et al. performed a study on 33 patients with 12 urologists, resulting in 396 patient-urologist interactions [105]. All urologists changed their final diagnostics in at least one patient case with the addition of Cxbladder results. The total number of requested invasive procedures was reduced from 425 to $379(-11 \%)$ following disclosure of Cxbladder information. Another study obtained the same results-a reduction in the number of total and invasive procedures [106]. The CxBladder detect assay is FDA approved.

\subsection{Non-Commercialized Urine DNA/RNA Tests \\ 3.2.1. uCAPP-Seq}

uCAPP-Seq is a novel high-throughput sequencing (HTS) method for the detection of urine tumor DNA (utDNA) called utDNA CAPP-Seq (uCAPP-Seq) [107]. DNA contained in urine is purified and sequenced. Around $311 \mathrm{~kb}$ of genome are covered, including 460 genes. At first, an analysis of 67 healthy adults and $118 \mathrm{BC}$ patients with different disease stages was performed [107]. The authors found a median of 6 mutations per tested patient; around $70 \%$ of mutations found in urine were the same found in the tumor. The two most common mutated regions were TERT (74\%) and PLEKHS1 promoters (46\%). BC common gene mutations, such as TP53, FGFR3, ERBB2, and RB1, were found, but there was no correlation between the total counted mutations and the stage of the disease. However, there was a correlation between urine DNA concentration and $\mathrm{BC}$ risk. As a new diagnostic test, uCAPP-Seq identified $77 \%$ of low-grade cancer and $100 \%$ of higher stage cancer. For surveillance of BC, cytology was positive for $37.8 \%$ of the patients who developed recurrence, while utDNA was positive in $84 \%$ of the cases. uCAPP-Seq is more efficient in detecting $B C$ recurrence than cytology; it has a higher rate of detection for low-grade BC than cytology. There is only one publication on uCAPP-Seq, and more work needs to be done to compare and validate this new test to other techniques. It will probably be expensive, but not as expensive as cystoscopy, and costs can be reduced, especially if this technique is used widely. The uCAPP-Seq assay is not yet commercialized.

\subsubsection{UroSEEK}

The UroSEEK assay enables the detection of specific DNA mutations contained in exfoliated urine cells to diagnose BC and upper tract urothelial carcinomas [108]. This assay targets intragenic mutations in specific regions of the ten following genes (FGFR3, TP53, CDKN2A, ERBB2, HRAS, KRAS, PIK3CA, MET, VHL and MLL), which are frequently mutated in urothelial tumors. It also targets mutations in the TERT promoter and detects aneuploidy. It is based on a singleplex PCR assay to analyze the TERT promoter region and a multiplex PCR assay to analyze the 10 genes regions, followed by sequencing [109]. By adding barcodes to the primers, it could detect mutations in as few as $0.03 \%$ of urinary cells. UroSEEK has been tested in three independent cohorts of patients [108]. For the BC early detection, results were compared, when possible, to mutations found in the biopsy of the 
initial tumor. By testing mutations of only 10 genes, there were false-negative results due to a low number of cancer cells in the urine $(62 \%$ of the cases) or to the absence of mutations in the tested genes ( $38 \%$ of the cases). By combining the three tests (10 genes mutations, TERT mutations, and aneuploidy), false-positive results were drastically reduced, with only 1 positive result among the 188 healthy patients, reaching a sensitivity of $83 \%$. Among the 395 patients in the BC early detection cohort who did not develop BC during the course of the study, $6.5 \%$ scored positive with the UroSEEK test. Despite the false positives, BC was detected 2.3 months before the diagnosis with gold standard techniques (cytology and cystoscopy), and, for 8 cases, more than one year before. By combining a complete UroSEEK test with the golden standard diagnosis test (cytology), a sensitivity of 95\% was achieved, a 12\% increase over UroSEEK and a 52\% increase over cytology and a 93\% specificity. For the BC surveillance cohort, a specificity of $80 \%$ and sensitivity of $71 \%$ were achieved; in combination with cytology, a specificity of $82 \%$ was reached. The UroSEEK test was positive 7 months before $\mathrm{BC}$ recurrence was diagnosed.

Another study was conducted in 2019 on 527 BC cases, including 373 low-grade and 154 high-grade bladder carcinomas (high grade) treated with transurethral resections or cystectomies [109]. Tumor and not urine-contained cells were analyzed, and white blood cells from healthy patient were used as control. A total of $92 \%$ of BC tumors were positive for at least one genetic alteration covered by UroSEEK test, including $70 \%$ positive for TERT mutations.

UroSEEK allows false-positive and false-negative diagnostics. False-negative results are mostly $\mathrm{BC}$ induced by mutations not detected by the UroSEEK test and, also, because of the low number of cells contained in urine. In fact, for some cancer, no cells were released into urine, at least at the early stage, and they can be diluted with normal cells [110]. UroSEEK should never be used as the only diagnostic test because there are too many falsenegative results. However it could be useful for detecting BC recurrence, as it can detect cancerous cells seven months before currently used techniques (cytology and cystoscopy), and mutations covered $90 \%$ of BC [109]. Even with a false-positive, it will help to drastically diminish the use of cystoscopy. In order to avoid false-negative results during followup, primary tumors could be sequenced to validate if this cancer can be detected by the UroSEEK assay. the UroSEEK assay is not yet commercialized.

\subsubsection{Assure $\mathrm{Mdx}$}

In the Assure Mdx assay, DNA is extracted from voided urine and analyzed for mutations in FGFR3, TERT, and HRAS, and methylation of OTX1, ONECUT2, and TWIST1 [111]. Assure Mdx was tested on 200 patients, including 97 with BC and 103 with nonmalignant profiles. The authors observed a sensitivity of $93 \%$ and a specificity of $86 \%$ for BC detection. These first results are promising but more work is needed to conclude on this technique, including comparison to golden standards, at least with cytology. Preliminary results suggest that Assure Mdx could be used for BC follow-up to help reduce cystoscopy and, perhaps, to help for the first diagnostic if sensitivity and specificity are better than with cytology. Assure Mdx is not yet commercialized.

\subsubsection{AURKA}

The Aurora kinase A (AURKA) gene encodes a key regulator of mitosis and is frequently amplified and/or overexpressed in cancer [112]. The level of AURKA amplification is associated with the level of aneuploidy. AURKA overexpression is associated with poor clinical outcomes due to increased cell cycle progression and development of genomic instability with aneuploidy $[113,114]$. In this assay, the AURKA gene copy number and DNA ploidy (centromeres for chromosomes 3, 7 and 17) are analyzed by FISH [112]. If three or more AURKA copies are detected, the sample is considered positive for BC. Firstly, 23 BC patients and 7 healthy control (training set) were analyzed, and then 100 BC patients and 148 control subjects (92 healthy individuals and 56 patients with benign disorders) were analyzed [112]. A specificity of $96.6 \%$ and a sensitivity of $87 \%$ were found. Another 
study based on 232 patients with BC and 255 control samples, as well as 126 from healthy individuals and 129 from patients with benign urologic disorders, was led. A FISH test for the AURKA gene copy number in urine yielded to a specificity of $80 \%$ and a sensitivity of $80 \%$ [113]. One of the problems resulting from using AURKA is that, when it is positive, the type of cancer concerned is not clear; it could be kidney cancer or other types of cancer with a leak of cells into urine. AURKA is also a target for the treatment of BC; AURKA tests can only be used prior to any treatment, for initial BC detection. The AURKA based assay is not yet commercialized.

\subsubsection{DNA Methylation}

There are a multitude of urine DNA methylation-based assays that are developed to detect BC. In fact, gene methylation is different in cancerous cells and can help to distinguish them from healthy cells and, also, from other cancer types or grades. DNA methylation is correlated with poor survival in BC patients [115].

One of the tests allows the quantification of EOMES, HOXA9, POU4F2, TWIST1, VIM, and ZNF154 methylation levels by real-time PCR (MethyLight) [116]. A total of 390 urine samples from 184 patients with low grade BC and 35 healthy patients were studied. For all six markers, independently, a sensitivity between $82 \%$ and $89 \%$ and a specificity between $94 \%$ and $100 \%$, for BC first detection, were obtained. For BC recurrence surveillance, a sensitivity between $88 \%$ and $94 \%$ and a specificity between $43 \%$ and $67 \%$ were obtained. It appears that hypermethylation was consistently present in urine samples for a group of healthy patients $(n=15-31 \%)$.

Another test quantifies promoter methylation of 8 genes (ARF, TIMP3, RAR- $\beta 2$, NID2, CCNA1, AIM1, CALCA and CCND2) by quantitative methylation-specific PCR (QMSP) [117]. A total of 17 nonrecurrent and 19 recurrent BCs were tested to identify optimum combinations, and new markers were found to study and explore. Other prospective confirmatory studies are needed to validate and optimize this assay. A larger cohort is, in fact, needed to obtain specificity and sensitivity rates.

Epicheck is an assay assessing the methylation status of 15 methylation markers [118]. D'Andrea et al. investigated the clinical utility and influence on decision making of the Bladder Epicheck assay for the surveillance of NMIBC using 440 patients [119]. A specificity of $88 \%$ was found to detect $\mathrm{BC}$ relapse.

Another study investigated voided urine methylation status to identify BC presence and grade [120]. Methylation status of 5 genes (TWIST1, RUNX3, GATA4, NID2 and FOXE1) was studied with a qPCR-based MethylLight assay. Using 211 BC patients (including 180 low grade) and 102 controls, they finally focused on 2 different markers and obtained a sensitivity of $76 \%$ and a specificity of $83 \%$ for BC detection, and $78 \%$ and $61 \%$ for grade determination.

A test developed for cervical cancer detection with DNA methylation, GynTect, has been used to detect $B C$ [121]. It usually permits the quantification of DNA methylation on 6 genes (ASTN1, DLX1, ITGA4, RXFP3, SOX17 and ZNF671). By modifying the algorithm, reducing the assay to 4 genes (DLX1, ITGA4, SOX17 and ZNF671), and testing on 30 patients with NMIBC and 30 control subjects, a sensitivity of $60 \%$ and a specificity of $96.7 \%$ were obtained. By adding others markers known to be modified in BC, this test could be optimized.

As DNA methylation may be dependent on patients' ethnicities, assays are developed on a specific cohort, such as one on a Chinese patient [122]. A combination of 7 genes (HOXA9, ONECUT2, PCDH17, PENK, TWIST1, VIM and ZNF154) was used to assess its ability to detect $\mathrm{BC}$ using a high-resolution melting-curve assay. Encouraging results were obtained on a small cohort, and a larger cohort is scheduled.

DNA methylation quantification is a noninvasive test that enables the detection of $\mathrm{BC}$, independent of specific mutations. One of the problems that may result from using DNA methylation is that, when it is positive, the cancer origin is not defined; it could be kidney cancer or any other type of cancer with cells leaking in the urine. As a minimum 
number of cells is necessary to detect methylation, $35 \%$ of patients were excluded because of an insufficient amount of DNA [116]. Next, a collection of $50 \mathrm{~mL}$ of urine or a use of alternative techniques, such as nested PCR, for example, are recommended by the authors. Another limitation could be the treatment used, such as BCG, mitomycin C, etc. Indeed, many of them could alter methylation status and there is a real lack of results in this field. It does not seem that DNA methylation quantification can replace cytology and cystoscopy for the initial detection of $\mathrm{BC}$ presently; the two golden techniques are more efficient. But this new technique has better sensitivity than cytology, and could, therefore, replace this technique for recurrence surveillance, allowing for the reduction of cystoscopy frequency.

\subsubsection{Uromonitor}

The Uromonitor assay allows for the detection of TERT promoter mutations and FGFR3 hotspot mutations in tumor cells exfoliated into urine samples [123]. Cells are filtrated from urine and analyzed with multiplex competitive allele-specific discrimination PCR. The Uromonitor assay has been tested in 185 samples to assess its sensitivity and specificity against cytology/cystoscopy. A sensitivity of $73.5 \%$ and a specificity of $93.2 \%$ for $\mathrm{BC}$ recurrence detection were obtained. These results are comparable to cystoscopy and better than cytology, according to the authors [123]. When used with cystoscopy, they obtained $100 \%$ sensitivity and $88.6 \%$ specificity. This assay could be completed with the detection of KRAS, as it shows encouraging results. However, $20 \%$ of BC does not seem to be detected by the Uromonitor assay, probably due to the fact that not all BCs are reported to have TERT promoter and FRGFR3 mutations. Uromonitor could be used for monitoring $\mathrm{BC}$ recurrence, and not $\mathrm{BC}$ primary diagnostic, because more than $20 \%$ of first $\mathrm{BC}$ tumors are not due to TERT promoter or FGFR3 mutations. The use of Uromonitor in the replacement of cytology could improve confidence at detecting $\mathrm{BC}$ recurrence and diminish cystoscopy frequency.

\section{Discussion}

Liquid biopsies are increasingly used for the diagnosis and follow-up of cancer patients. Indeed, urine and blood are largely used as liquid biopsies to detect markers, such as circulating cell free DNA, microRNA, circular RNA, non-coding RNA, proteins, cells etc. [124-126]. Urine is a body fluid that can be used to detect cancers and others diseases. It is noninvasive and easy to collect. Other types of cancer, completely independent of the genitourinary system, can also be detected using urine, such as breast cancer or Glioblastoma [124]. To detect BC, cytology is the first assay used. It is an effective way to detect high-grade BC and CIS, but with a high rate of equivocal results, especially for low-grade BC. As such, cystoscopy is used to confirm cytology results and to determine cancer status. Cystoscopy is also effective, but invasive, recurrent, and not well accepted by all patients, especially during $B C$ follow-up. As shown in this review, numerous assays were developed during the past few years in order to diagnose $\mathrm{BC}$ at an early stage, and to facilitate the follow-up of patients. For BC screening, an assay should be less invasive (noninvasive, if possible) with a high sensitivity, especially for low grade $\mathrm{BC}$, but it is also important to have a high specificity to avoid further unnecessary invasive procedures. Therefore, it should not be solely based on morphology and should be sufficient to detect BC at any stage. Most of the assays described in this review do not fit these criteria, or, at least, are used in combination with cytology and cystoscopy, such as ImmunoCyt $/ \mathrm{uCyt}^{\mathrm{TM}}$. Some assays are dedicated to one specific stage of BC, such as Assure Mdx and Xpert assays. Some of the tests could not be used for the initial diagnostic, such as NMP22 BladderChek ${ }^{\circledR}$, Urovysion or Cxbladder. This is one of the critical points-the tests do not allow detection of $B C$ at an early stage with high sensitivity.

For diagnosis, an assay's specificity and sensitivity must be very high. Price should not be an issue, as a low number of persons would undergo it based on an efficient screening assay. None of the assays described above can compete with cystoscopy for definitive diagnosis. 
For the follow-up of patients, one of the major issues is the invasiveness of tests and their repetition over time. The recurrence of these invasive tests can lead to urinary tract infections, pain, or discomfort, leading to the patient's own discontinuation of followup care. In addition, lifelong follow-up leads to heavy financial burdens. Therefore, noninvasive assays with a high specificity, high sensitivity, and moderate cost would be greatly beneficial. Many of the assays described here could, or are, used as follow-up assays, especially because some of them have high specificity and sensitivity, and are specific to stages of BC and as easy to perform as BTA assays. Therefore, follow-up assays could be selected according to patient profile and effectiveness. Urovysion assays and UroSEEK assays seem to work for BC recurrence detection.

To date, assays are efficient in the advanced BC stage for the diagnosis and follow-up of patients. Unfortunately, for the initial screening of patients, especially for low-grade cancer patients, assays lack effectiveness. These types of assays are crucial, as they could save lives by detecting BC sooner. They could also considerably reduce overall BC cost. New assays are in development and there are not enough data available yet to describe them in this review, but they could fill some of the gap in the future. Thus, miRNA could be used to develop diagnostic tests for bladder cancer, since they are stable in body fluids and could, therefore, be easily used to develop noninvasive tests. In fact, several miRNA misregulations are associated with bladder cancer development and outcome prediction, such as miRNA-155, 21-miRNA, miRNA-1178, etc. [127-129]. An interesting meta-analysis about urine miRNA tests to detect BC was published in 2018 [130]. According to Kutwin et al., a test studying multiple miRNA, and not just one, could compete with cytology tests; however, there is still a need to perform clinical trials to validate this hypothesis. Another possible future test is based on an improved cytology reading thanks to artificial intelligence. A specific urine preparation could allow the visualization of urothelial cells, coupled with an image processing algorithm of urinary cytology slides. This assay, called Visiocyt, is described as sensitive for low-grade BC. Other assays could rely on next generation sequencing (NGS), allowing detection of a low amount of cancer DNA in urine.

Supplementary Materials: The following are available online at https:/ /www.mdpi.com/article/10 .3390/cancers13071650/s1, Table S1: Performances of non-invasive tests.

Author Contributions: R.P. was responsible for the ideation, M.C. and C.G. performed the literature search and analysis; M.C., C.G., T.G., G.V. and R.P. drafted the manuscript; M.C., C.G. and R.P. revised the manuscript. All authors have read and agreed to the published version of the manuscript.

Funding: M.C., C.G., T.G. and R.P. were funded by Region Bretagne, European Regional Development Fund, Rennes Metropole, VitaDX, University Rennes 1 and INSERM.

Institutional Review Board Statement: Not applicable.

Informed Consent Statement: Not applicable.

Data Availability Statement: Not applicable.

Acknowledgments: We are grateful to Laëtitia Lallement and Allan Rodriguez for kindly reviewing this manuscript, and to Pratticò for language editing.

Conflicts of Interest: The authors received fundings from VitaDX.

\section{References}

1. Binder-Foucard, F.; Bossard, N.; Delafosse, P.; Belot, A.; Woronoff, A.-S.; Remontet, L. Cancer Incidence and Mortality in France over the 1980-2012 Period: Solid Tumors. Rev. DÉpidémiol. Santé Publique 2014, 62, 95-108. [CrossRef]

2. Leal, J.; Luengo-Fernandez, R.; Sullivan, R.; Witjes, J.A. Economic Burden of Bladder Cancer Across the European Union. Eur. Urol. 2016, 69, 438-447. [CrossRef] [PubMed]

3. Farling, K.B. Bladder Cancer: Risk Factors, Diagnosis, and Management. Nurse Pract. 2017, 42, 26-33. [CrossRef] [PubMed]

4. Amin, M.B.; Greene, F.L.; Edge, S.B.; Compton, C.C.; Gershenwald, J.E.; Brookland, R.K.; Meyer, L.; Gress, D.M.; Byrd, D.R.; Winchester, D.P. The Eighth Edition AJCC Cancer Staging Manual: Continuing to Build a Bridge from a Population-Based to a More "Personalized" Approach to Cancer Staging. CA Cancer J. Clin. 2017, 67, 93-99. [CrossRef] 
5. Griffiths, T.R.L. Current Perspectives in Bladder Cancer Management. Int. J. Clin. Pract. 2013, 67, 435-448. [CrossRef] [PubMed]

6. Sharp, V.J.; Barnes, K.T.; Erickson, B.A. Assessment of Asymptomatic Microscopic Hematuria in Adults. Am. Fam. Phys. 2013, 88,8 .

7. Barkan, G.A.; Wojcik, E.M.; Nayar, R.; Savic-Prince, S.; Quek, M.L.; Kurtycz, D.F.I.; Rosenthal, D.L. The Paris System for Reporting Urinary Cytology: The Quest to Develop a Standardized Terminology. Acta Cytol. 2016, 60, 185-197. [CrossRef]

8. Owens, C.L.; Vanden Bussche, C.J.; Burroughs, F.H.; Rosenthal, D.L. A Review of Reporting Systems and Terminology for Urine Cytology. Cancer Cytopathol. 2013, 121, 9-14. [CrossRef] [PubMed]

9. Rouprêt, M.; Pignot, G.; Masson-Lecomte, A.; Compérat, E.; Audenet, F.; Roumiguié, M.; Houédé, N.; Larré, S.; Brunelle, S.; Xylinas, E.; et al. Recommandations françaises du Comité de cancérologie de l'AFU—Actualisation 2020-2022: Tumeurs de la vessie. Prog. En Urol. 2020, 30, S78-S135. [CrossRef]

10. Zhu, C.-Z.; Ting, H.-N.; Ng, K.-H.; Ong, T.-A. A Review on the Accuracy of Bladder Cancer Detection Methods. J. Cancer 2019, 10, 4038-4044. [CrossRef]

11. Malmström, P.-U.; Agrawal, S.; Bläckberg, M.; Boström, P.J.; Malavaud, B.; Zaak, D.; Hermann, G.G. Non-Muscle-Invasive Bladder Cancer: A Vision for the Future. Scand. J. Urol. 2017, 51, 87-94. [CrossRef] [PubMed]

12. Pfister, C.; Roupret, M.; Neuzillet, Y.; Larré, S.; Pignot, G.; Quintens, H.; Houedé, N.; Compérat, E.; Colin, P.; Roy, C.; et al. Recommandations en onco-urologie 2013 du CCAFU: Tumeurs de la vessie. Prog. Urol. 2013, 23, S105-S125. [CrossRef]

13. Oeyen, E.; Hoekx, L.; De Wachter, S.; Baldewijns, M.; Ameye, F.; Mertens, I. Bladder Cancer Diagnosis and Follow-Up: The Current Status and Possible Role of Extracellular Vesicles. Int. J. Mol. Sci. 2019, 20, 821. [CrossRef] [PubMed]

14. Sloan, F.A.; Yashkin, A.P.; Akushevich, I.; Inman, B.A. The Cost to Medicare of Bladder Cancer Care. Eur. Urol. Oncol. 2020, 3 , 515-522. [CrossRef] [PubMed]

15. Barratt, J.; Topham, P. Urine Proteomics: The Present and Future of Measuring Urinary Protein Components in Disease. Can. Med. Assoc. J. 2007, 177, 361-368. [CrossRef] [PubMed]

16. Thomas, C.E.; Sexton, W.; Benson, K.; Sutphen, R.; Koomen, J. Urine Collection and Processing for Protein Biomarker Discovery and Quantification. Cancer Epidemiol. Biomark. Prev. 2010, 19, 953-959. [CrossRef]

17. The Finn Bladder Group; Raitanen, M.-P.; Kaasinen, E.; Rintala, E.; Hansson, E.; Nieminen, P.; Aine, R.; Tammela, T.L.J. Prognostic Utility of Human Complement Factor H Related Protein Test (the BTA Stat ${ }^{\circledR}$ Test). Br. J. Cancer 2001, 85, 552-556. [CrossRef]

18. Kinders, R.; Jones, T.; Root, R.; Bruce, C.; Murchison, H.; Corey, M.; Williams, L.; Enfield, D.; Hass, G.M. Complement Factor H or a Related Protein Is a Marker for Transitional Cell Cancer of the Bladder. Clin. Cancer Res. 1998, 4, 2511-2520.

19. Gutiérrez Baños, J.L.; Rodrigo, M.d.H.R.; Juárez, F.M.A.; García, B.M. Usefulness of the BTA Stat Test for the Diagnosis of Bladder Cancer. Urology 2001, 57, 685-689. [CrossRef]

20. Thomas, L.; Leyh, H.; Marberger, M.; Bombardieri, E.; Bassi, P.; Pagano, F.; Pansadoro, V.; Sternberg, C.N.; Boccon-Gibod, L.; Ravery, V.; et al. Multicenter Trial of the Quantitative BTA TRAK Assay in the Detection of Bladder Cancer. Clin. Chem. 1999, 45, 472-477.

21. Shariat, S.F.; Karam, J.A.; Lotan, Y.; Karakiewizc, P.I. Critical Evaluation of Urinary Markers for Bladder Cancer Detection and Monitoring. Rev. Urol. 2008, 10, 120-135. [PubMed]

22. Campos-Fernandes, J.-L.; Descotes, F.; André, J.; Perrin, P.; Devonec, M.; Ruffion, A. Value of urinary markers in the diagnosis and follow-up of urothelial bladder tumours. Prog. Urol. J. Assoc. Fr. Urol. Soc. Fr. Urol. 2007, 17, 23-34. [CrossRef]

23. Budman, L.I.; Kassouf, W.; Steinberg, J.R. Biomarkers for Detection and Surveillance of Bladder Cancer. Can. Urol. Assoc. J. 2008, 2, 212-221. [CrossRef] [PubMed]

24. Bibbo, M.; Kern, W.H. Chapter 15-Urinary Tract. In Comprehensive Cytopathology, 3rd ed.; Bibbo, M., Wilbur, D., Eds.; W.B. Saunders: Edinburgh, UK, 2008; pp. 409-437. ISBN 978-1-4160-4208-2.

25. Miyanaga, N.; Akaza, H.; Tsukamoto, T.; Ishikawa, S.; Noguchi, R.; Ohtani, M.; Kawabe, K.; Kubota, Y.; Fujita, K.; Obata, K.; et al. Urinary Nuclear Matrix Protein 22 as a New Marker for the Screening of Urothelial Cancer in Patients with Microscopic Hematuria. Int. J. Urol. 1999, 6, 173-177. [CrossRef]

26. Balci, M.; Tuncel, A.; Guzel, O.; Aslan, Y.; Sezgin, T.; Bilgin, O.; Senel, C.; Atan, A. Use of the Nuclear Matrix Protein 22 Bladder Chek Test ${ }^{\mathrm{TM}}$ in the Diagnosis of Residual Urothelial Cancer before a Second Transurethral Resection of Bladder Cancer. Int. Urol. Nephrol. 2015, 47, 473-477. [CrossRef] [PubMed]

27. Gellhaus, P.T.; Genetic Aberrations in Bladder Cancer, Fluorescence in Situ Hybridization. In Urine Tumor Markers in Bladder Cancer Diagnosis: Overview of Urine Tumor Markers; 2020. Available online: https://emedicine.medscape.com/article/195302 2-overview (accessed on 1 March 2021).

28. Mowatt, G.; Zhu, S.; Kilonzo, M.; Boachie, C.; Fraser, C.; Griffiths, T.R.L.; N’Dow, J.; Nabi, G.; Cook, J.; Vale, L. Systematic Review of the Clinical Effectiveness and Cost-Effectiveness of Photodynamic Diagnosis and Urine Biomarkers (FISH, ImmunoCyt, NMP22) and Cytology for the Detection and Follow-up of Bladder Cancer. Health Technol. Assess. 2010, 14, 1-331. [CrossRef]

29. Moonen, P.M.J.; Kiemeney, L.A.L.M.; Witjes, J.A. Urinary NMP22 ${ }^{\circledR}$ BladderChek ${ }^{\circledR}$ Test in the Diagnosis of Superficial Bladder Cancer. Eur. Urol. 2005, 48, 951-956. [CrossRef]

30. Doğan, C.; Pelit, E.S.; Yıldırım, A.; Zemheri, I.E.; Çanakcı, C.; Başok, E.K.; Çaşkurlu, T. The Value of the NMP22 Test for Superficial Bladder Cancer Diagnosis and Follow-Up. Turk. J. Urol. 2013, 39, 137-142. [CrossRef] [PubMed]

31. Kumar, A.; Kumar, R.; Gupta, N.P. Comparison of NMP22 BladderChek Test and Urine Cytology for the Detection of Recurrent Bladder Cancer. Jpn. J. Clin. Oncol. 2006, 36, 172-175. [CrossRef] 
32. Fradet, Y.; Larue, H.; Parent-Vaugeois, C.; Bergeron, A.; Dufour, C.; Boucher, L.; Bernier, L. Monoclonal Antibody against a Tumor-Associated Sialoglycoprotein of Superficial Papillary Bladder Tumors and Cervical Condylomas. Int. J. Cancer 1990, 46, 990-997. [CrossRef]

33. Bergeron, A.; LaRue, H.; Fradet, Y. Identification of a Superficial Bladder Tumor-Associated Glycoform of the Carcinoembryonic Antigen by Monoclonal Antibody 19A211. Cancer Res. 1996, 56, 908-915. [PubMed]

34. Têtu, B.; Tiguert, R.; Harel, F.; Fradet, Y. ImmunoCyt/UCyt $+{ }^{\mathrm{TM}}$ Improves the Sensitivity of Urine Cytology in Patients Followed for Urothelial Carcinoma. Mod. Pathol. 2005, 18, 83-89. [CrossRef] [PubMed]

35. Bergeron, A.; Champetier, S.; LaRue, H.; Fradet, Y. MAUB Is a New Mucin Antigen Associated with Bladder Cancer. J. Biol. Chem. 1996, 271, 6933-6940. [CrossRef]

36. Bergeron, A.; LaRUE, H.; Fradet, Y. Biochemical Analysis of a Bladder-Cancer-Associated Mucin: Structural Features and Epitope Characterization. Biochem. J. 1997, 321, 889-896. [CrossRef]

37. Allard, P.; Fradet, Y.; Têtu, B.; Bernard, P. Tumor-Associated Antigens as Prognostic Factors for Recurrence in 382 Patients with Primary Transitional Cell Carcinoma of the Bladder. Clin. Cancer Res. 1995, 1, 1195-1202. [PubMed]

38. Greene, K.L.; Berry, A.; Konety, B.R. Diagnostic Utility of the ImmunoCyt/uCyt ${ }^{+}$Test in Bladder Cancer. Rev. Urol. 2006, 8, 190-197.

39. Piaton, E.; Daniel, L.; Verriele, V.; Dalifard, I.; Zimmermann, U.; Renaudin, K.; Gobet, F.; Caratero, A.; Desvaux, D.; Pouille, Y.; et al. Improved Detection of Urothelial Carcinomas with Fluorescence Immunocytochemistry (UCyt+ Assay) and Urinary Cytology: Results of a French Prospective Multicenter Study. Lab. Investig. 2003, 83, 845-852. [CrossRef] [PubMed]

40. Schmitz-Dräger, C.; Bonberg, N.; Pesch, B.; Todenhöfer, T.; Sahin, S.; Behrens, T.; Brüning, T.; Schmitz-Dräger, B.J. Replacing Cystoscopy by Urine Markers in the Follow-up of Patients with Low-Risk Non-Muscle-Invasive Bladder Cancer?-An International Bladder Cancer Network Project. Urol. Oncol. Semin. Orig. Investig. 2016, 34, 452-459. [CrossRef]

41. Kassouf, W.; Traboulsi, S.L.; Schmitz-Dräger, B.; Palou, J.; Witjes, J.A.; van Rhijn, B.W.G.; Grossman, H.B.; Kiemeney, L.A.; Goebell, P.J.; Kamat, A.M. Follow-up in Non-Muscle-Invasive Bladder Cancer-International Bladder Cancer Network Recommendations. Urol. Oncol. Semin. Orig. Investig. 2016, 34, 460-468. [CrossRef]

42. Björklund, B.; Björklund, V. Antigenicity of Pooled Human Malignant and Normal Tissues by Cyto-Immunological Technique: Presence of an Insoluble, Heat-Labile Tumor Antigen. Int. Arch. Allergy Immunol. 1957, 10, 153-184. [CrossRef]

43. Lüning, B.; Wiklund, B.; Redelius, P.; Björklund, B. Biochemical Properties of Tissue Polypeptide Antigen. Biochim. Biophys. Acta BBA Protein Struct. 1980, 624, 90-101. [CrossRef]

44. Maulard-Durdux, C.; Toubert, M.E.; Hennequin, C.; Housset, M. Serum Tissue Polypeptide Antigen in Bladder Cancer as a Tumor Marker: A Prospective Study. J. Clin. Oncol. 1997, 15, 3446-3450. [CrossRef] [PubMed]

45. Sánchez-Carbayo, M.; Urrutia, M.; Silva, J.M.; Romaní, R.; García, J.; Alférez, F.; González de Buitrago, J.M.; Navajo, J.A. Urinary Tissue Polypeptide-Specific Antigen for the Diagnosis of Bladder Cancer. Urology 2000, 55, 526-532. [CrossRef]

46. Ritter, R.; Hennenlotter, J.; Kühs, U.; Hofmann, U.; Aufderklamm, S.; Blutbacher, P.; Deja, A.; Hohneder, A.; Gerber, V.; Gakis, G.; et al. Evaluation of a New Quantitative Point-of-Care Test Platform for Urine-Based Detection of Bladder Cancer. Urol. Oncol. Semin. Orig. Investig. 2014, 32, 337-344. [CrossRef] [PubMed]

47. Ecke, T.H.; Arndt, C.; Stephan, C.; Hallmann, S.; Lux, O.; Otto, T.; Ruttloff, J.; Gerullis, H. Preliminary Results of a Multicentre Study of the UBC Rapid Test for Detection of Urinary Bladder Cancer. Anticancer Res. 2015, 35, 2651-2655.

48. Ecke, T.H.; Weiß, S.; Stephan, C.; Hallmann, S.; Barski, D.; Otto, T.; Gerullis, H. UBC ${ }^{\circledR}$ Rapid Test for Detection of Carcinoma in Situ for Bladder Cancer. Tumor Biol. 2017, 39, 101042831770162. [CrossRef]

49. Pichler, R.; Tulchiner, G.; Fritz, J.; Schaefer, G.; Horninger, W.; Heidegger, I. Urinary UBC Rapid and NMP22 Test for Bladder Cancer Surveillance in Comparison to Urinary Cytology: Results from a Prospective Single-Center Study. Int. J. Med. Sci. 2017, 14, 811-819. [CrossRef]

50. Mourant, A.E. A 'New' Human Blood Group Antigen of Frequent Occurrence. Nature 1946, 158, 237-238. [CrossRef]

51. Itzkowitz, S.H.; Yuan, M.; Fukushi, Y.; Palekar, A.; Phelps, P.C.; Shamsuddin, A.M.; Trump, B.F.; Hakomori, S.; Kim, Y.S. Lewis ${ }^{-}$ and Sialylated Lewis ${ }^{\mathrm{X}}$-Related Antigen Expression in Human Malignant and Nonmalignant Colonie Tissues. Cancer Res. 1986, 46, 2627-2632.

52. Pode, D.; Golijanin, D.; Sherman, Y.; Lebensart, P.; Shapiro, A. Immunostaining of Lewis X in cells from voided urine, cytopathology and ultrasound for noninvasive detection of bladder tumors. J. Urol. 1998, 159, 389-393. [CrossRef]

53. Planz, B.; Synek, C.; Deix, T.; Böcking, A.; Marberger, M. Diagnosis of Bladder Cancer with Urinary Cytology, Immunocytology and DNA-Image-Cytometry. Anal. Cell. Pathol. 2001, 22, 103-109. [CrossRef] [PubMed]

54. Golijanin, D.; Sherman, Y.; Shapiro, A.; Pode, D. Detection of Bladder Tumors by Immunostaininc of the Lewis x Antigen in Cells from Voided Urine. Urology 1995, 46, 173-177. [CrossRef]

55. Ambrosini, G.; Adida, C.; Altieri, D.C. A Novel Anti-Apoptosis Gene, Survivin, Expressed in Cancer and Lymphoma. Nat. Med. 1997, 3, 917-921. [CrossRef]

56. Li, F.; Ambrosini, G.; Chu, E.Y.; Plescia, J.; Tognin, S.; Marchisio, P.C.; Altieri, D.C. Control of Apoptosis and Mitotic Spindle Checkpoint by Survivin. Nature 1998, 396, 580-584. [CrossRef] [PubMed]

57. Li, F.; Ackermann, E.J.; Bennett, C.F.; Rothermel, A.L.; Plescia, J.; Tognin, S.; Villa, A.; Marchisio, P.C.; Altieri, D.C. Pleiotropic Cell-Division Defects and Apoptosis Induced by Interference with Survivin Function. Nat. Cell Biol. 1999, 1, 461-466. [CrossRef] 
58. Altieri, D.C.; Marchisio, P.C.; Marchisio, C. Survivin Apoptosis: An Interloper between Cell Death and Cell Proliferation in Cancer. Lab. Investig. 1999, 79, 1327-1333.

59. Reed, J.C. The Survivin Saga Goes In Vivo. J. Clin. Investig. 2001, 108, 965-969. [CrossRef]

60. Satoh, K.; Kaneko, K.; Hirota, M.; Masamune, A.; Satoh, A.; Shimosegawa, T. Expression of Survivin Is Correlated with Cancer Cell Apoptosis and Is Involved in the Development of Human Pancreatic Duct Cell Tumors. Cancer 2001, 92, 271-278. [CrossRef]

61. Tanaka, C.; Uzawa, K.; Shibahara, T.; Yokoe, H.; Noma, H.; Tanzawa, H. Expression of an Inhibitor of Apoptosis, Survivin, in Oral Carcinogenesis. J. Dent. Res. 2003, 82, 607-611. [CrossRef]

62. Dallaglio, K.; Marconi, A.; Pincelli, C. Survivin: A Dual Player in Healthy and Diseased Skin. J. Investig. Dermatol. 2012, 132, 18-27. [CrossRef]

63. Eissa, S.; Swellam, M.; Shehata, H.; El-Khouly, I.M.; El-Zayat, T.; El-Ahmady, O. Expression of HYAL1 and Survivin RNA as Diagnostic Molecular Markers for Bladder Cancer. J. Urol. 2010, 183, 493-498. [CrossRef]

64. Wang, H.; Xi, X.; Kong, X.; Huang, G.; Ge, G. The Expression and Significance of Survivin MRNA in Urinary Bladder Carcinomas. J. Cancer Res. Clin. Oncol. 2004, 130, 487-490. [CrossRef]

65. Smith, S.D.; Wheeler, M.A.; Plescia, J.; Colberg, J.W.; Weiss, R.M.; Altieri, D.C. Urine Detection of Survivin and Diagnosis of Bladder Cancer. JAMA 2001, 285, 324-328. [CrossRef]

66. Lokeshwar, V.B.; Block, N.L. HA-HAase URINE TEST: A Sensitive and Specific Method for Detecting Bladder Cancer and Evaluating Its Grade. Urol. Clin. N. Am. 2000, 27, 53-61. [CrossRef]

67. Knudson, W. Tumor-Associated Hyaluronan. Am. J. Pathol. 1996, 148, 1721-1726. [PubMed]

68. Pham, H.T.; Block, N.L.; Lokeshwar, V.B. Tumor-Derived Hyaluronidase: A Diagnostic Urine Marker for High-Grade Bladder Cancer. Cancer Res. 1997, 57, 778. [CrossRef] [PubMed]

69. Kramer, M.W.; Golshani, R.; Merseburger, A.S.; Knapp, J.; Garcia, A.; Hennenlotter, J.; Duncan, R.C.; Soloway, M.S.; Jorda, M.; Kuczyk, M.A.; et al. HYAL-1 Hyaluronidase: A Potential Prognostic Indicator for Progression to Muscle Invasion and Recurrence in Bladder Cancer. Eur. Urol. 2010, 57, 86-94. [CrossRef] [PubMed]

70. Morera, D.S.; Hennig, M.S.; Talukder, A.; Lokeshwar, S.D.; Wang, J.; Garcia-Roig, M.; Ortiz, N.; Yates, T.J.; Lopez, L.E.; Kallifatidis, G.; et al. Hyaluronic Acid Family in Bladder Cancer: Potential Prognostic Biomarkers and Therapeutic Targets. Br. J. Cancer 2017, 117, 1507-1517. [CrossRef] [PubMed]

71. Van Tilborg, A.A.G.; Bangma, C.H.; Zwarthoff, E.C. Bladder Cancer Biomarkers and Their Role in Surveillance and Screening. Int. J. Urol. 2009, 16, 23-30. [CrossRef]

72. Parker, J.; Spiess, P.E. Current and Emerging Bladder Cancer Urinary Biomarkers. Sci. World J. 2011, 11, 1103-1112. [CrossRef]

73. Liang, Z.; Zhang, Q.; Wang, C.; Shi, F.; Cao, H.; Yu, Y.; Zhang, M.; Liu, X. Hyaluronic Acid/ Hyaluronidase as Biomarkers for Bladder Cancer: A Diagnostic Meta-Analysis. Neoplasma 2017, 64, 901-908. [CrossRef]

74. Konety, B.R.; Nguyen, T.-S.T.; Dhir, R.; Day, R.S.; Becich, M.J.; Stadler, W.M.; Getzenberg, R.H. Detection of Bladder Cancer Using a Novel Nuclear Matrix Protein, BLCA-4. Clin. Cancer Res. 2000, 6, 2618-2625.

75. Getzenberg, R.H.; Konety, B.R.; Oeler, T.A.; Quigley, M.M.; Hakam, A.; Becich, M.J.; Bahnson, R.R. Bladder Cancer-Associated Nuclear Matrix Proteins. Cancer Res. 1996, 56, 1690.

76. Myers-Irvin, J.M.; Landsit, D.; Getzenberg, R.H. Use of the novel marker blca-1 for the detection of bladder cancer. J. Urol. 2005, 174, 64-68. [CrossRef]

77. Santoni, M.; Catanzariti, F.; Minardi, D.; Burattini, L.; Nabissi, M.; Muzzonigro, G.; Cascinu, S.; Santoni, G. Pathogenic and Diagnostic Potential of BLCA-1 and BLCA-4 Nuclear Proteins in Urothelial Cell Carcinoma of Human Bladder. Adv. Urol. 2012, 2012, 397412. [CrossRef]

78. Lotan, Y.; Roehrborn, C.G. Sensitivity and Specificity of Commonly Available Bladder Tumor Markers versus Cytology: Results of a Comprehensive Literature Review and Meta-Analyses. Urology 2003, 61, 109-118. [CrossRef]

79. Cai, Q.; Wu, Y.; Guo, Z.; Gong, R.; Tang, Y.; Yang, K.; Li, X.; Guo, X.; Niu, Y.; Zhao, Y. Urine BLCA-4 Exerts Potential Role in Detecting Patients with Bladder Cancers: A Pooled Analysis of Individual Studies. Oncotarget 2015, 6, 37500-37510. [CrossRef] [PubMed]

80. Wang, S.; Xia, T.; Zhang, Z.; Kong, X.; Zeng, L.; Mi, P.; Xue, Z. Expression of VEGF and Tumor Angiogenesis in Bladder Cancer. Zhonghua Wai Ke Za Zhi 2000, 38, 34-36.

81. Schmetter, B.S.; Habicht, K.K.; Lamm, D.L.; Morales, A.; Bander, N.H.; Grossman, H.B.; Hanna, M.G.J.; Silberman, S.R.; Butman, B.T. A Multicenter Trial Evaluation of the Fibrin/Fibrinogen Degradation Products Test for Detection and Monitoring of Bladder Cancer. J. Urol. 1997, 158, 801-805. [CrossRef]

82. Topsakal, M.; Karadeniz, T.; Anaç, M.; Dönmezer, S.; Besisik, A. Assessment of Fibrin-Fibrinogen Degradation Products (Accu-Dx) Test in Bladder Cancer Patients. Eur. Urol. 2001, 39, 287-291. [CrossRef] [PubMed]

83. Wajsman, Z.; Williams, P.D.; Greco, J.; Murphy, G.P. Further Study of Fibrinogen Degradation Products in Bladder Cancer Detection. Urology 1978, 12, 659-661. [CrossRef]

84. Label INCa-HAS-Surveillance Médico-Professionnelle des Travailleurs Exposés ou Ayant Eté Exposés à des Agents Cancérogènes Chimiques: Application aux Cancérogènes Pour la Vessie. Available online: https://www.has-sante.fr/jcms/c_12 46108/fr/label-inca-has-surveillance-medico-professionnelle-des-travailleurs-exposes-ou-ayant-ete-exposes-a-des-agentscancerogenes-chimiques-application-aux-cancerogenes-pour-la-vessie (accessed on 14 April 2020). 
85. Silvers, C.R.; Miyamoto, H.; Messing, E.M.; Netto, G.J.; Lee, Y.-F. Characterization of Urinary Extracellular Vesicle Proteins in Muscle-Invasive Bladder Cancer. Oncotarget 2017, 8, 91199-91208. [CrossRef] [PubMed]

86. Lin, S.-Y.; Chang, C.-H.; Wu, H.-C.; Lin, C.-C.; Chang, K.-P.; Yang, C.-R.; Huang, C.-P.; Hsu, W.-H.; Chang, C.-T.; Chen, C.-J. Proteome Profiling of Urinary Exosomes Identifies Alpha 1-Antitrypsin and H2B1K as Diagnostic and Prognostic Biomarkers for Urothelial Carcinoma. Sci. Rep. 2016, 6, 34446. [CrossRef]

87. Silvers, C.R.; Liu, Y.-R.; Wu, C.-H.; Miyamoto, H.; Messing, E.M.; Lee, Y.-F. Identification of Extracellular Vesicle-Borne Periostin as a Feature of Muscle-Invasive Bladder Cancer. Oncotarget 2016, 7, 23335-23345. [CrossRef] [PubMed]

88. Hunter, T. Signaling-2000 and Beyond. Cell 2000, 100, 113-127. [CrossRef]

89. Sakamoto, K.; Kadomatsu, K. Midkine in the Pathology of Cancer, Neural Disease, and Inflammation. Pathol. Int. 2012, 62, 445-455. [CrossRef] [PubMed]

90. Jones, D.R. Measuring Midkine: The Utility of Midkine as a Biomarker in Cancer and Other Diseases. Br. J. Pharmacol. 2014, 171, 2925-2939. [CrossRef]

91. Ikematsu, S.; Okamoto, K.; Yoshida, Y.; Oda, M.; Sugano-Nagano, H.; Ashida, K.; Kumai, H.; Kadomatsu, K.; Muramatsu, H.; Muramatsu, T.; et al. High Levels of Urinary Midkine in Various Cancer Patients. Biochem. Biophys. Res. Commun. 2003, 306, 329-332. [CrossRef]

92. Shimwell, N.J.; Bryan, R.T.; Wei, W.; James, N.D.; Cheng, K.K.; Zeegers, M.P.; Johnson, P.J.; Martin, A.; Ward, D.G. Combined Proteome and Transcriptome Analyses for the Discovery of Urinary Biomarkers for Urothelial Carcinoma. Br. J. Cancer 2013, 108, 1854-1861. [CrossRef]

93. Soukup, V.; Kalousová, M.; Capoun, O.; Sobotka, R.; Breyl, Z.; Pešl, M.; Zima, T.; Hanuš, T. Panel of Urinary Diagnostic Markers for Non-Invasive Detection of Primary and Recurrent Urothelial Urinary Bladder Carcinoma. Urol. Int. 2015, 95, 56-64. [CrossRef]

94. Vu Van, D.; Heberling, U.; Wirth, M.P.; Fuessel, S. Validation of the Diagnostic Utility of Urinary Midkine for the Detection of Bladder Cancer. Oncol. Lett. 2016, 12, 3143-3152. [CrossRef]

95. Luo, Y.; She, D.-L.; Xiong, H.; Yang, L.; Fu, S.-J. Diagnostic Value of Liquid-Based Cytology in Urothelial Carcinoma Diagnosis: A Systematic Review and Meta-Analysis. PLoS ONE 2015, 10, e0134940. [CrossRef]

96. Kapoor, K.; Datta, C.; Pal, D.K. Is Liquid-Based Cytology an Alternative to Conventional Cytology for Detection of Malignant Cells in Urine of Bladder Cancer? Eastern Indian Prospective Observational Study. Turk. J. Urol. 2019, 45, 351-356. [CrossRef] [PubMed]

97. Lee, H.; Kim, K.; Woo, J.; Park, J.; Kim, H.; Lee, K.E.; Kim, H.; Kim, Y.; Moon, K.C.; Kim, J.Y.; et al. Quantitative Proteomic Analysis Identifies AHNAK (Neuroblast Differentiation-Associated Protein AHNAK) as a Novel Candidate Biomarker for Bladder Urothelial Carcinoma Diagnosis by Liquid-Based Cytology. Mol. Cell. Proteom. 2018, 17, 1788-1802. [CrossRef]

98. Sokolova, I.A.; Halling, K.C.; Jenkins, R.B.; Burkhardt, H.M.; Meyer, R.G.; Seelig, S.A.; King, W. The Development of a Multitarget, Multicolor Fluorescence in Situ Hybridization Assay for the Detection of Urothelial Carcinoma in Urine. J. Mol. Diagn. JMD 2000, 2, 116-123. [CrossRef]

99. van Valenberg, F.J.P.; Strauss-Ayali, D.; Agmon-Gerstein, Y.; Friedman, A.; Arentsen, H.C.; Schaafsma, H.E.; Witjes, J.A.; Oosterwijk, E. Assessment of the Efficacy of Repeated Instillations of Mitomycin C Mixed with a Thermosensitive Hydrogel in an Orthotopic Rat Bladder Cancer Model. Ther. Adv. Urol. 2018, 10, 213-221. [CrossRef] [PubMed]

100. Yoder, B.J.; Skacel, M.; Hedgepeth, R.; Babineau, D.; Ulchaker, J.C.; Liou, L.S.; Brainard, J.A.; Biscotti, C.V.; Jones, J.S.; Tubbs, R.R Reflex UroVysion Testing of Bladder Cancer Surveillance Patients with Equivocal or Negative Urine Cytology: A Prospective Study with Focus on the Natural History of Anticipatory Positive Findings. Am. J. Clin. Pathol. 2007, 127, 295-301. [CrossRef]

101. Kojima, T.; Nishiyama, H.; Ozono, S.; Hinotsu, S.; Keino, N.; Yamaguchi, A.; Sakai, H.; Enomoto, Y.; Horie, S.; Fujimoto, K.; et al. Clinical Evaluation of Two Consecutive UroVysion Fluorescence in Situ Hybridization Tests to Detect Intravesical Recurrence of Bladder Cancer: A Prospective Blinded Comparative Study in Japan. Int. J. Clin. Oncol. 2018, 23, 1140-1147. [CrossRef]

102. Holyoake, A.; O’Sullivan, P.; Pollock, R.; Best, T.; Watanabe, J.; Kajita, Y.; Matsui, Y.; Ito, M.; Nishiyama, H.; Kerr, N.; et al. Development of a Multiplex RNA Urine Test for the Detection and Stratification of Transitional Cell Carcinoma of the Bladder. Clin. Cancer Res. 2008, 14, 742-749. [CrossRef] [PubMed]

103. O'Sullivan, P.; Sharples, K.; Dalphin, M.; Davidson, P.; Gilling, P.; Cambridge, L.; Harvey, J.; Toro, T.; Giles, N.; Luxmanan, C.; et al. A Multigene Urine Test for the Detection and Stratification of Bladder Cancer in Patients Presenting with Hematuria. J. Urol. 2012, 188, 741-747. [CrossRef]

104. Kavalieris, L.; O’Sullivan, P.J.; Suttie, J.M.; Pownall, B.K.; Gilling, P.J.; Chemasle, C.; Darling, D.G. A Segregation Index Combining Phenotypic (Clinical Characteristics) and Genotypic (Gene Expression) Biomarkers from a Urine Sample to Triage out Patients Presenting with Hematuria Who Have a Low Probability of Urothelial Carcinoma. BMC Urol. 2015, 15, 23. [CrossRef] [PubMed]

105. Darling, D.; Luxmanan, C.; O'Sullivan, P.; Lough, T.; Suttie, J. Clinical Utility of Cxbladder for the Diagnosis of Urothelial Carcinoma. Adv. Ther. 2017, 34, 1087-1096. [CrossRef] [PubMed]

106. Lough, T.; Luo, Q.; O'Sullivan, P.; Chemaslé, C.; Stotzer, M.; Suttie, J.; Darling, D. Clinical Utility of Cxbladder Monitor for Patients with a History of Urothelial Carcinoma: A Physician-Patient Real-World Clinical Data Analysis. Oncol. Ther. 2018, 6, 73-85. [CrossRef]

107. Dudley, J.C.; Schroers-Martin, J.; Lazzareschi, D.V.; Shi, W.Y.; Chen, S.B.; Esfahani, M.S.; Trivedi, D.; Chabon, J.J.; Chaudhuri, A.A.; Stehr, H.; et al. Detection and Surveillance of Bladder Cancer Using Urine Tumor DNA. Cancer Discov. 2019, 9, 500-509. [CrossRef] 
108. Springer, S.U.; Chen, C.-H.; Rodriguez Pena, M.D.C.; Li, L.; Douville, C.; Wang, Y.; Cohen, J.D.; Taheri, D.; Silliman, N.; Schaefer, J.; et al. Non-Invasive Detection of Urothelial Cancer through the Analysis of Driver Gene Mutations and Aneuploidy. eLife 2018, 7. [CrossRef]

109. Eich, M.-L.; Rodriguez Pena, M.D.C.; Springer, S.U.; Taheri, D.; Tregnago, A.C.; Salles, D.C.; Bezerra, S.M.; Cunha, I.W.; Fujita, K.; Ertoy, D.; et al. Incidence and Distribution of UroSEEK Gene Panel in a Multi-Institutional Cohort of Bladder Urothelial Carcinoma. Mod. Pathol. 2019, 32, 1544-1550. [CrossRef]

110. de Jong, J.J.; Liu, Y.; Robertson, A.G.; Seiler, R.; Groeneveld, C.S.; van der Heijden, M.S.; Wright, J.L.; Douglas, J.; Dall'Era, M.; Crabb, S.J.; et al. Long Non-Coding RNAs Identify a Subset of Luminal Muscle-Invasive Bladder Cancer Patients with Favorable Prognosis. Genome Med. 2019, 11, 60. [CrossRef]

111. van Kessel, K.E.M.; Beukers, W.; Lurkin, I.; Ziel-van der Made, A.; van der Keur, K.A.; Boormans, J.L.; Dyrskjøt, L.; Márquez, M.; Ørntoft, T.F.; Real, F.X.; et al. Validation of a DNA Methylation-Mutation Urine Assay to Select Patients with Hematuria for Cystoscopy. J. Urol. 2017, 197, 590-595. [CrossRef]

112. Park, H.-S.; Park, W.S.; Bondaruk, J.; Tanaka, N.; Katayama, H.; Lee, S.; Spiess, P.E.; Steinberg, J.R.; Wang, Z.; Katz, R.L.; et al. Quantitation of Aurora Kinase A Gene Copy Number in Urine Sediments and Bladder Cancer Detection. J. Natl. Cancer Inst. 2008, 100, 1401-1411. [CrossRef]

113. Mobley, A.; Zhang, S.; Bondaruk, J.; Wang, Y.; Majewski, T.; Caraway, N.P.; Huang, L.; Shoshan, E.; Velazquez-Torres, G.; Nitti, G.; et al. Aurora Kinase A Is a Biomarker for Bladder Cancer Detection and Contributes to Its Aggressive Behavior. Sci. Rep. 2017, 7, 40714. [CrossRef]

114. Burgess, E.F.; Livasy, C.; Trufan, S.; Hartman, A.; Guerreri, R.; Naso, C.; Clark, P.E.; Grigg, C.; Symanowski, J.; Raghavan, D. High Aurora Kinase Expression Identifies Patients with Muscle-Invasive Bladder Cancer Who Have Poor Survival after Neoadjuvant Chemotherapy. Urol. Oncol. 2019, 37, 900-906. [CrossRef] [PubMed]

115. Wang, L.; Shi, J.; Huang, Y.; Liu, S.; Zhang, J.; Ding, H.; Yang, J.; Chen, Z. A Six-Gene Prognostic Model Predicts Overall Survival in Bladder Cancer Patients. Cancer Cell Int. 2019, 19, 229. [CrossRef] [PubMed]

116. Reinert, T.; Borre, M.; Christiansen, A.; Hermann, G.G.; Ørntoft, T.F.; Dyrskjøt, L. Diagnosis of Bladder Cancer Recurrence Based on Urinary Levels of EOMES, HOXA9, POU4F2, TWIST1, VIM, and ZNF154 Hypermethylation. PLoS ONE 2012, 7, e46297. [CrossRef]

117. Maldonado, L.; Brait, M.; Michailidi, C.; Munari, E.; Driscoll, T.; Schultz, L.; Bivalacqua, T.; Schoenberg, M.; Sidransky, D.; Netto, G.J.; et al. An Epigenetic Marker Panel for Recurrence Risk Prediction of Low Grade Papillary Urothelial Cell Carcinoma (LGPUCC) and Its Potential Use for Surveillance after Transurethral Resection Using Urine. Oncotarget 2014, 5, 5218-5233. [CrossRef] [PubMed]

118. Leal, A.; Sidransky, D.; Brait, M. Tissue and Cell-Free DNA-Based Epigenomic Approaches for Cancer Detection. Clin. Chem. 2020, 66, 105-116. [CrossRef]

119. D'Andrea, D.; Soria, F.; Zehetmayer, S.; Gust, K.M.; Korn, S.; Witjes, J.A.; Shariat, S.F. Diagnostic Accuracy, Clinical Utility and Influence on Decision-Making of a Methylation Urine Biomarker Test in the Surveillance of Non-Muscle-Invasive Bladder Cancer. BJU Int. 2019, 123, 959-967. [CrossRef]

120. Hermanns, T.; Savio, A.J.; Olkhov-Mitsel, E.; Mari, A.; Wettstein, M.S.; Saba, K.; Bhindi, B.; Kuk, C.; Poyet, C.; Wild, P.J.; et al. A Noninvasive Urine-Based Methylation Biomarker Panel to Detect Bladder Cancer and Discriminate Cancer Grade. Urol. Oncol. 2020, 38, 603.e1-603.e7. [CrossRef]

121. Steinbach, D.; Kaufmann, M.; Hippe, J.; Gajda, M.; Grimm, M.-O. High Detection Rate for Non-Muscle-Invasive Bladder Cancer Using an Approved DNA Methylation Signature Test. Clin. Genitourin. Cancer 2020, 18, 210-221. [CrossRef]

122. Zhang, N.; Chen, S.; Wu, L.; Wu, Y.; Jiang, G.; Shao, J.; Chen, L.; Sun, J.; Na, R.; Wang, X.; et al. Identification of Cancer-Specific Methylation of Gene Combination for the Diagnosis of Bladder Cancer. J. Cancer 2019, 10, 6761-6766. [CrossRef]

123. Batista, R.; Vinagre, J.; Prazeres, H.; Sampaio, C.; Peralta, P.; Conceição, P.; Sismeiro, A.; Leão, R.; Gomes, A.; Furriel, F.; et al. Validation of a Novel, Sensitive, and Specific Urine-Based Test for Recurrence Surveillance of Patients with Non-Muscle-Invasive Bladder Cancer in a Comprehensive Multicenter Study. Front. Genet. 2019, 10, 1237. [CrossRef]

124. Birkó, Z.; Nagy, B.; Klekner, Á.; Virga, J. Novel Molecular Markers in Glioblastoma-Benefits of Liquid Biopsy. Int. J. Mol. Sci. 2020, 21, 7522. [CrossRef] [PubMed]

125. Pisapia, P.; Malapelle, U.; Troncone, G. Liquid Biopsy and Lung Cancer. Acta Cytol. 2019, 63, 489-496. [CrossRef] [PubMed]

126. Alimirzaie, S.; Bagherzadeh, M.; Akbari, M.R. Liquid Biopsy in Breast Cancer: A Comprehensive Review. Clin. Genet. 2019, 95, 643-660. [CrossRef] [PubMed]

127. Wang, H.; Men, C.-P. Correlation of Increased Expression of MicroRNA-155 in Bladder Cancer and Prognosis. Lab. Med. 2015, 46, 118-122. [CrossRef] [PubMed]

128. Yin, X.-H.; Jin, Y.-H.; Cao, Y.; Wong, Y.; Weng, H.; Sun, C.; Deng, J.-H.; Zeng, X.-T. Development of a 21-MiRNA Signature Associated With the Prognosis of Patients With Bladder Cancer. Front. Oncol. 2019, 9, 729. [CrossRef] [PubMed]

129. Bi, J.; Liu, H.; Dong, W.; Xie, W.; He, Q.; Cai, Z.; Huang, J.; Lin, T. Circular RNA Circ-ZKSCAN1 Inhibits Bladder Cancer Progression through MiR-1178-3p/P21 Axis and Acts as a Prognostic Factor of Recurrence. Mol. Cancer 2019, 18, 133. [CrossRef]

130. Kutwin, P.; Konecki, T.; Jabłonowski, Z. Urine MiRNA as a Potential Biomarker for Bladder Cancer Detection-A Meta-Analysis. Cent. Eur. J. Urol. 2018, 71, 177-185. [CrossRef] 